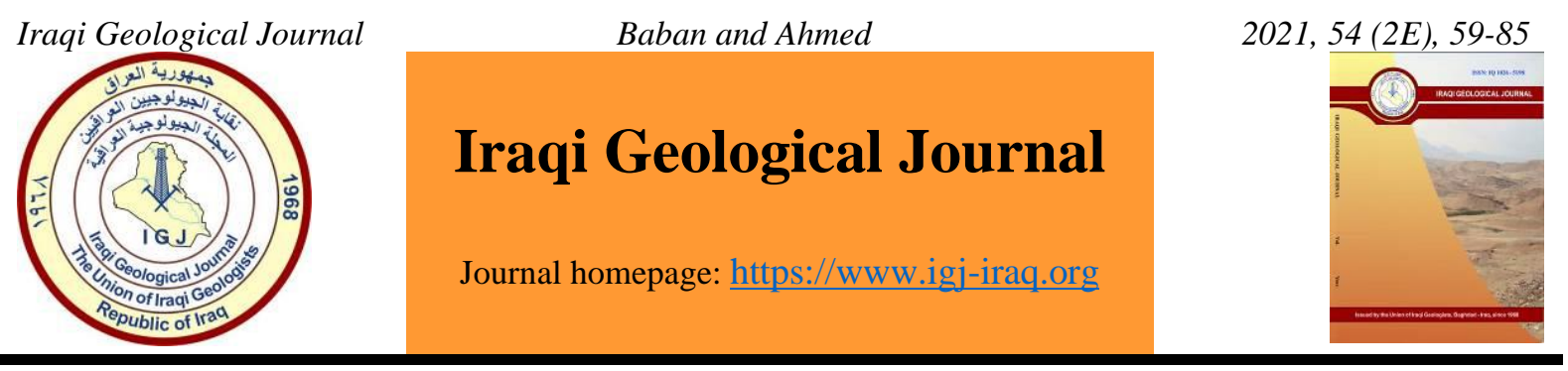

\title{
Source Rocks' Potentiality of the Sargelu Formation (Middle Jurassic) in the Taq Taq Oilfield, Kurdistan Region, Iraq
}

\author{
Dler H. Baban ${ }^{1, *}$ and Shadan M. Ahmed ${ }^{1}$ \\ 1 Department of Geology, College of Science, University of Sulaimani, Iraq \\ * Correspondence: dler.mohamad@univsul.edu.iq
}

Received: 24 June 2021; Accepted: 7 August 2021; Published: 30 November 2021

\begin{abstract}
Thirty rock samples were selected from the well Tq-1 that penetrated the Jurassic beds in the Taq Taq Oilfield to be studied the source rock potentiality of the Sargelu Formation. The formation is characterized by three types of microfacies, namely, foraminiferal packstone, grainstone microfacies, fossiliferous packstone microfacies, and foraminiferal wackestone which were deposited in an environment extending from middle to outer carbonate ramp. An average of $3.03 \mathrm{wt} . \%$ of total organic carbon was obtained from a Rock Eval pyrolysis analysis carried out on 24 selected rock samples. The petrographic analysis for such organic matters revealed that they are of kerogen types III and IV and they are currently in a post-mature state. Pyrolysis parameters showed that limited generation potential was remained for these sources to expel generated hydrocarbons. The palynological study showed that Amorphous Organic Matter forms the highest percentage of organic matter components with more than $70 \%$, followed by phytoclasts with $10-25 \%$ and palynomorphs of less than $10 \%$. The organic matters within the Sargelu Formation are deposited at the distal part of the basin under suboxic to anoxic condition. The color of the organic matter components, examined under transmitted light, showed Thermal Alteration Index values between $3+$ and $4-$. Such values may indicate that these organic matters are thermally at the end of the liquid oil generation zone and beginning of condensate-wet gas generation zone. The thermal maturity of the Sargelu Formation depending on the calculated VRo\% revealed that the formation in the studied oilfield is currently at the peak of the oil generation zone. The Sargelu Formation in the studied field is considered as an effective source rock, as it has already generated and expelled hydrocarbons.
\end{abstract}

Keywords: Sargelu Formation; Taq Taq Field; Organic matter; Pyrolysis; Total organic carbon; Source rock

\section{Introduction}

Taq Taq Oilfield is located in Zagros Oil Province in the Kurdistan Region of Iraq, about $61 \mathrm{Km}$ northeast of Kirkuk City and about $120 \mathrm{Km}$ northwest of Sulaimani City (Fig.1). Tectonically, this field is located within the Zagros Fold Belt Zone, the northeast unit of the Foot Hill Zone (ButmahChemchemal Subzone) (Jassim and Goff, 2006). The field, discovered at the end of the 1950s by the Iraqi Petroleum Company (IPC), and it has an obvious reflection of its structure on the ground surface and Landsat images. Being one of the most important productive oilfields in the Iraqi Kurdistan Region in the last 15 years, a lot of research was published focusing on its reservoirs and source rocks (Baban and Sarraj, 2007; Baban and Ahmed, 2008; Abdula, 2010; Garland et al., 2010; Othman and Al-Qayim, 
2010; Al-Qayim and Rashid, 2012; Al-Qayim and Othman, 2012; Baban and Ranyayi, 2013; Awdal et al., 2013; Abdula, 2015; Najaf, 2018; Hakimi et al., 2018; Baban et al., 2020).

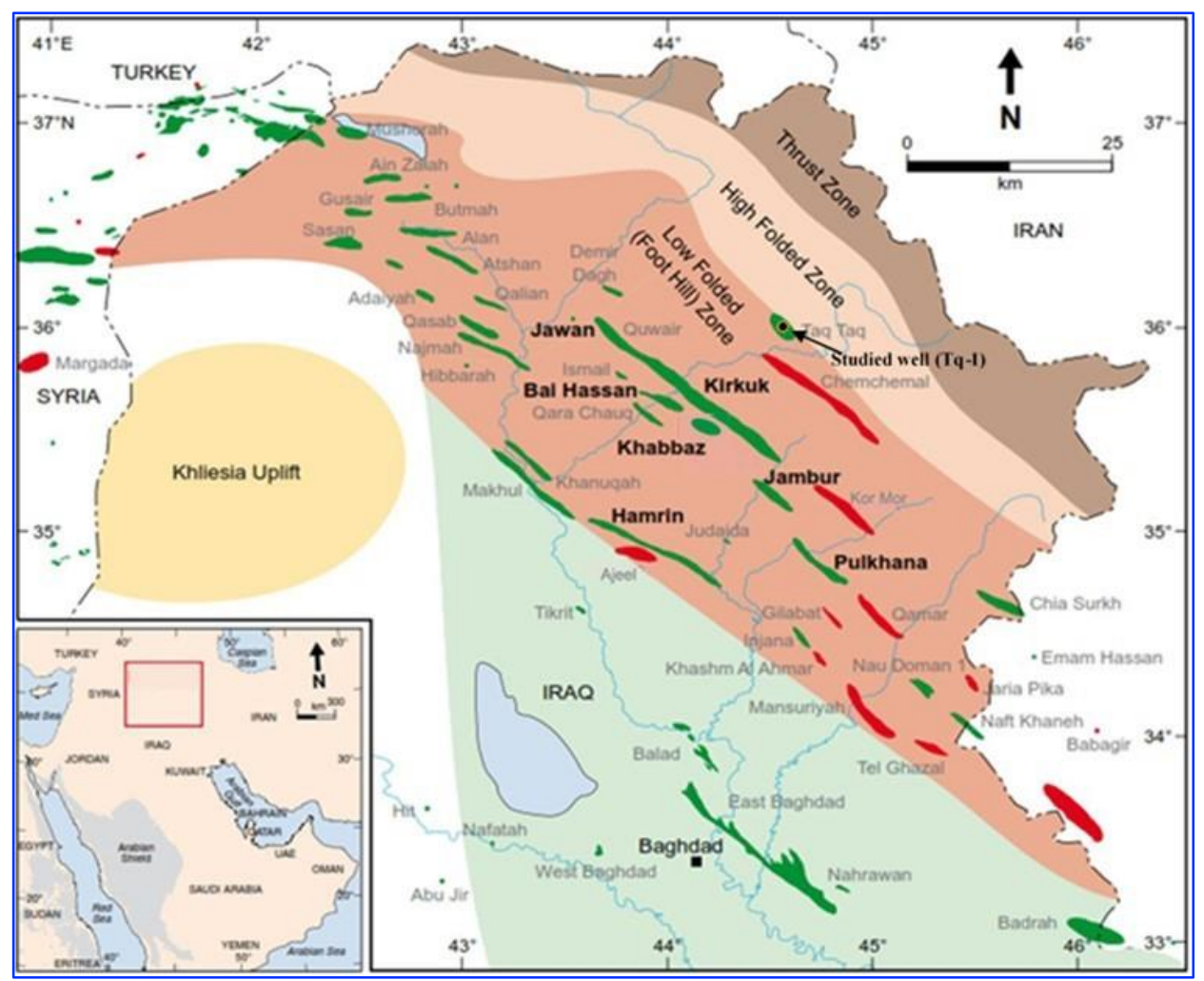

Fig.1. Tectonic subdivisions of Iraq and location of studied Taq Taq Field and the well Tq-1 (after Al-

Qayim et al., 2010).

There is a broad agreement that most of the accumulated oil in the Iraqi oilfield reservoirs is generated by the middle and upper Jurassic formations of Sargelu, Naokelekan, Barsarin, and Chia Gara. The properties of these formations as source rocks vary from place to place in the Iraqi territory. According to Aqrawi and Badics (2015), Sargelu Formation alone could have generated up to 7,100billion-barrel oil-equivalent (BBOE) petroleum in the Mesopotamian Foredeep Basin, and 5,600 BBOE in the Zagros Fold Belt. In this study, an attempt is made to evaluate potentiality of the Sargelu Formation as a source rock from the well Tq-1 that has penetrated the formation in the Taq Taq Oilfield. Different tools are used in the evaluation process and the results compared with work previously done on the same formation in nearby areas (Ahmed, 2001; Pitman et al., 2004; Al-Ahmed, 2006; Al-Ameri et al., 2014; Abdula, 2015; English et al., 2015; Fatah and Mohialdeen, 2016; Najaf, 2018, Hakimi et al., 2018; Kobraei et al., 2019; Mamaseni, 2020).

\section{Stratigraphy}

\subsection{Sargelu Formation}

The Sargelu Formation was first described and identified by Wetzel in 1948, and that in Surdash anticline, Sulaimaniya District, Northeastern Iraq. The type section is located in a stream course that flows northwards through Sargelu Village/ Surdash Anticline, with coordinates; Long. 45 9' 25" E, and Lat. 35 52' 44" N (Bellen et al., 1959). The formation has outcrops on various structures in the Imbricated Zone, Northern Thrust Zone, and High Folded Zone (Balambo-Tanjero Tectonic Subzone), 
as well as the tectonic framework of the Qulqula-Khwakurk Tectonic Zone. It is distributed in the subsurface all over Iraq, except the Rutba Subzone, where it passes laterally into the Muhaiwir Formation (Buday, 1980; Jassim and Buday, 2006). The formation also has outcrops at many other localitieswithin Kurdistan Region, such as the Sirwan, Sehkaniyan, Qal'Gah, Rania, Naokelekan, Kurrek, and Rowanduz areas. The thickness of the Sargelu Formation is about $115 \mathrm{~m}$ in its type section, and this varies from $20 \mathrm{~m}$ to $125 \mathrm{~m}$ in other outcrops in the Northern Thrust, Imbricated, and High Folded zones. The thickness is much greater and varies between around $250 \mathrm{~m}$ and $500 \mathrm{~m}$ in the subsurface sections (wells) of the Foothill and Mesopotamian Zones of the Unstable Shelf (Buday, 1980; Pitman et al., 2004). Lithologically, the Sargelu Formation consists of thin bedded, black bituminous and dolomitic limestone, black papery shale with a streak of thin black chert in the upper part (Bellen et al., 1959; Aqrawi et al., 2010). The subsurface sections contain a greater amount of shale and a sandy mixture has sometimes been noticed towards the west (Jassim and Buday, 2006). Four lithofacies types were identified by Balaky (2004) in selected outcrop sections of the Sargelu Formation in the Kurdistan region, namely: massive bedded dolomite, Bositra limestone, cherty limestone, and argillaceous limestone.The age of the Sargelu Formation has been determined as uppermost Liassic at the base and Bathonian at the top, based on fossils evidence (Bellen et al., 1959; Buday, 1980) which are plentiful in both surface and subsurface sections.

In the Ru Kuchuk area, there were silty and plant impressions in the lower part of Posidonia and chert bearing divisions of the Sargelu Formation, which are good indicators of the proximity of emerged land to the northeast (Bellen et al., 1959). According to Murris (1980), the Sargelu Formation was probably deposited in a euxinic marine environment under an anoxic stratified condition. The existence of some interlayers representing either shallower or more oxidized conditions is another indication of deposition in the Stable Shelf area (tongues of Muhaiwir Formation within the Sargelu Formation represent those shallow carbonates) (Buday, 1980; Jassim and Buday, 2006).

\section{The Study Area}

The structure of Taq Taq Field comprises a NW - SE trending longitudinal, asymmetrical double plunging anticline nearly $29 \mathrm{Km}$ in length and $11 \mathrm{~km}$ in width (IOEC, 1994). The average elevation of the field is about $600 \mathrm{~m}$ above sea level, and sediments of the Bakhtiari and Upper Fars formations cover the field structure at the surface.The studied well of Tq-1 is the first exploration well drilled in 1960, it is located near the crest of the Taq Taq anticline, with UTM coordinates $456583.300 \mathrm{E}$ and 3984 $150.400 \mathrm{~N}$, and an elevation of about $630.5 \mathrm{~m}$ above sea level (Fig.2). The Tq-1 well is considered to be the deepest drilled well in the field, it penetrates Tertiary, Cretaceous and Jurassic successions and crosses four pay (reservoir) zones, namely, Pila Spi, Shiranish, Kometan, and Qamchuqa (IOEC, 1994) (Fig.3). The Sargelu Formation (as one of the expected Jurassic sources of accumulated oil in the field) is located between depths of 3,242 $\mathrm{m}$ and 3,340 $\mathrm{m}$ in the Tq-1 well, with a drilled thickness of about 98m (NOC, 1978).

\section{Materials and Methods}

Thirty cutting and core samples were selected from well Tq-1 to study the Sargelu Formation (Table 1). The samples were chosen systematically as one sample for nearly five meters of depth for cutting and one sample for each meter in the cored interval covering the depth interval between 3,242 $\mathrm{m}$ and 3,340 m (Table 2). Rock-Eval pyrolysis analysis performed for 24 selected samples at the Kurdistan Institution for Strategic and Scientific Research in Sulaimani City, and at the Scientific Research Centre of Soran University in Erbil Governorate. Such an analysis is carried out to determine the quantity, quality and maturity of organic matter. Twenty-three palynological slides were prepared (one slide for each sample) for a microscopic study of different organic matter components of the extracted kerogens 
using transmitted light microscopy. Also, nine thin sections were prepared from nine selected samples to recognize different microfacies types.

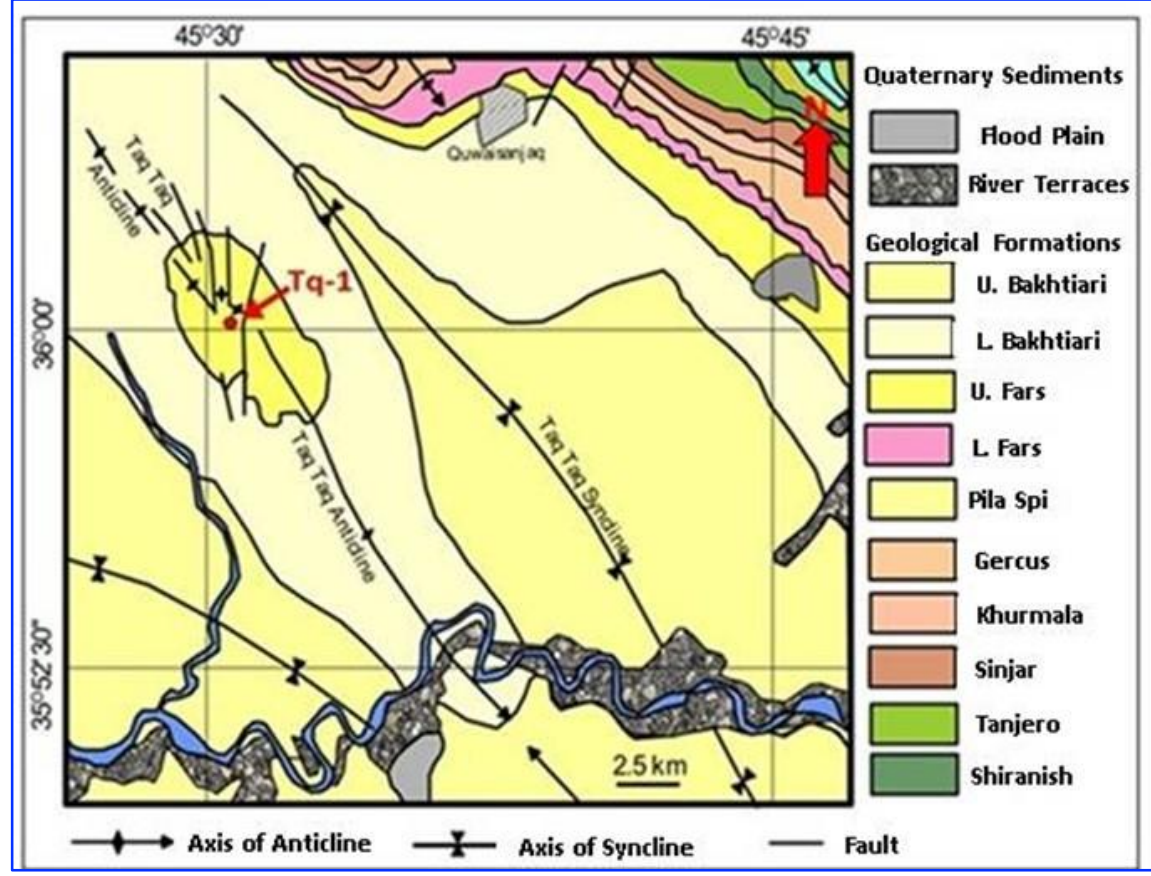

Fig.2. Location of the well Tq-1 on the geological map of Taq Taq structure

\section{Results}

\subsection{Microfacies Analysis of the Sargelu Formation}

Dunham (1962)'s classification was used for microfacies analysis of the Sargelu Formation in this study. Three main types of microfacies were identified, namely, foraminiferal packstone/ grainstone, foraminiferal packstone, and foraminiferal wackestone microfacies (Figs. 4A-C). These microfacies are described in more details below:

\subsubsection{Foraminiferal packstone/ grainstone microfacies}

This microfacies is mainly observed in the upper most and lower parts of the Sargelu Formation. Lithologically, this microfacies consists of black organic rich limestone and dolomitic limestone. It is characterized by the abundance of skeletal grains of benthic foraminifera including Siphovalvulina variabilis, Epistomina sp., Bosniella oenensis, Siphovalvulina sp., Lenticulina muensteri. (Figs. 5A-E respectively), Meandrovoluta asiagoensis, Pseudocyclammina sp., Ophthalmidium strumosum, Remondoedis lugeoni (Figs. 5G-L respectively), Orbitopsella primaeva (Fig. 6A), Haghimashella arcuata, Praepeneroplis senoniensis, Quinqueloculina sp. (Figs. 6C-E respectively).

Table 1. Total number of the studied samples, type of test done, and the prepared slides for the selected samples from the Sargelu Formation

\begin{tabular}{|c|c|c|c|c|c|c|c|c|}
\hline $\begin{array}{l}\text { Studied } \\
\text { well }\end{array}$ & Formation & $\begin{array}{l}\text { Thickness } \\
\text { (m) }\end{array}$ & $\begin{array}{l}\text { Sample } \\
\text { type }\end{array}$ & $\begin{array}{c}\text { Total number of } \\
\text { samples }\end{array}$ & $\begin{array}{c}\text { Rock-Eval } \\
\text { Pyrolysis }\end{array}$ & $\begin{array}{l}\text { Palynological } \\
\text { slides }\end{array}$ & $\begin{array}{c}\text { Thin } \\
\text { sections }\end{array}$ & $\begin{array}{c}\text { Polished } \\
\text { Resin } \\
\text { blocks }\end{array}$ \\
\hline \multirow[t]{2}{*}{ Tq-1 } & Sargelu & 98 & cutting & 25 & 20 & 19 & 7 & 3 \\
\hline & & & core & 5 & 4 & 4 & 2 & 1 \\
\hline Total & & & & 30 & 24 & 23 & 9 & 4 \\
\hline
\end{tabular}




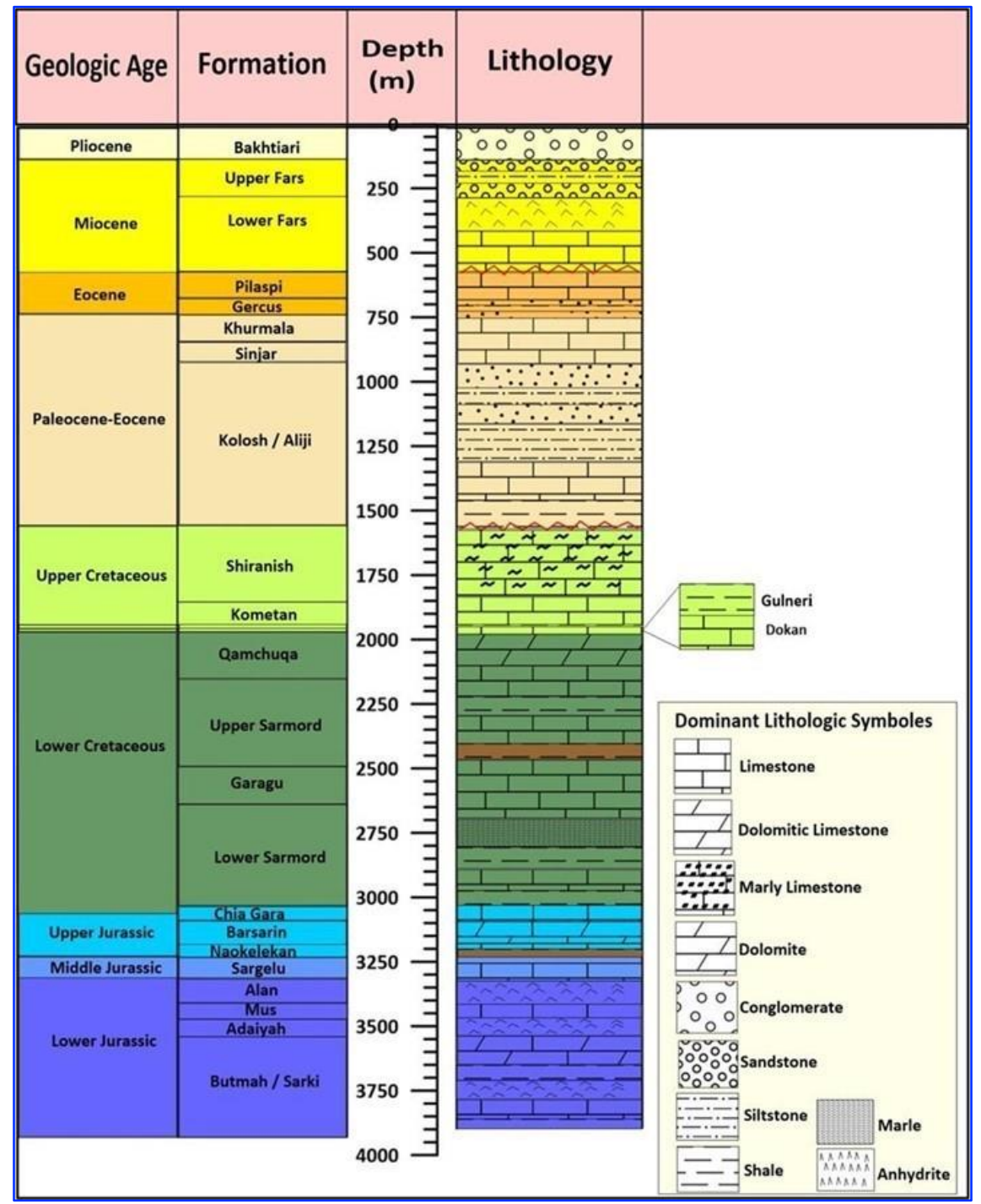

Fig.3. The stratigraphic column of the formations as penetrated by Tq-1 well in Taq Taq Oilfield

Also, bivalve debris with red and green algae were observed in this microfacies, including Nipponophycus ramosus (Fig. 5F) and Permocalculus sp. (Fig. 6B). The rock samples of this microfacies are highly bituminous. As a result, most of the fossils were impregnated with bitumen (Fig. 5B). According to Flugel (2010), this microfacies belongs to RMF4, which should be deposited in a middle ramp environment.

\subsubsection{Foraminiferal packstone microfacies}

This microfacies is identified at a depth interval of $3250-3280 \mathrm{~m}$, where the lithology mostly comprises black organic-rich limestone and dolomitic limestone. The most abundant skeletal grains are benthic foraminifera, including Lenticulina sp. (Fig. 5M), and non-foraminiferal fossils such as algae represented by Permocalculus sp. and Nipponophycus ramosus (Figs. 5K and 5L respectively), in addition to radiolarian spines (Fig. 5O) and fragments of bivalves. This microfacies also belongs to RMF4, as per Flugel (2010), which indicates deposition in a middle ramp environment. 


\subsubsection{Foraminiferal wackestone microfacies}

This microfacies is only observed at a depth interval of $3280-3320 \mathrm{~m}$. The dominant lithologies are black argillaceous limestone rich in organic matter and black papery organic-rich shale. The foraminiferal species in this microfacies include Lenticulina sp., Phenacophragma assurgens, and Siphovalvulina colomi (Figs. 5N-P respectively). Bivalve debris is also noticeable in this microfacies, in addition to bitumen-filled fossils (Fig. 5Q). This microfacies corresponds to RMF3, which belongs to a middle and outer ramp carbonate depositional environment (Flugel, 2010).

Table 2. Depths of the selected samples for the pyrolysis, microfacies, palynological, and coal petrography study of the Sargelu Formation from Tq-1 well

\begin{tabular}{|c|c|c|c|c|c|}
\hline Sample & Depth (m) & $\begin{array}{c}\text { Rock-Eval } \\
\text { Pyrolysis } \\
\end{array}$ & $\begin{array}{c}\text { Thin } \\
\text { Sections } \\
\end{array}$ & $\begin{array}{c}\text { Palynological } \\
\text { Slides }\end{array}$ & $\begin{array}{c}\text { Organic } \\
\text { Petrography }\end{array}$ \\
\hline 1 & 3242 & $\diamond$ & & & \\
\hline 2 & 3245 & $\diamond$ & $\diamond$ & $\diamond$ & $\diamond$ \\
\hline 3 & 3250 & $\diamond$ & & $\diamond$ & \\
\hline 4 & 3255 & $\diamond$ & & & \\
\hline 5 & 3260 & $\diamond$ & & $\diamond$ & \\
\hline 6 & 3265 & $\diamond$ & & $\diamond$ & \\
\hline 7 & 3270 & $\diamond$ & $\diamond$ & $\diamond$ & \\
\hline 8 & 3275 & $\diamond$ & & & \\
\hline 9 & 3280 & $\diamond$ & & $\diamond$ & \\
\hline 10 & 3285 & $\diamond$ & & $\diamond$ & $\diamond$ \\
\hline 11 & 3290 & $\diamond$ & & $\diamond$ & \\
\hline 12 & 3295 & $\diamond$ & & $\diamond$ & \\
\hline 13 & 3300 & $\diamond$ & & $\diamond$ & \\
\hline 14 & 3303 & & $\diamond$ & $\diamond$ & \\
\hline 15 & 3305(core sample) & $\diamond$ & & $\diamond$ & \\
\hline 16 & 3307(core sample) & $\diamond$ & $\diamond$ & & $\diamond$ \\
\hline 17 & 3308(core sample) & $\diamond$ & & $\diamond$ & \\
\hline 18 & 3309 (core sample) & $\diamond$ & & $\diamond$ & \\
\hline 19 & 3310(core sample) & & $\diamond$ & $\diamond$ & \\
\hline 20 & 3311 & & & $\diamond$ & \\
\hline 21 & 3315 & $\diamond$ & & & \\
\hline 22 & 3320 & $\diamond$ & & $\diamond$ & \\
\hline 23 & 3322 & & $\diamond$ & & \\
\hline 24 & 3325 & $\diamond$ & & $\diamond$ & \\
\hline 25 & 3327 & & $\diamond$ & & \\
\hline 26 & 3330 & $\diamond$ & & $\diamond$ & $\diamond$ \\
\hline 27 & 3333 & & $\diamond$ & $\diamond$ & \\
\hline 28 & 3335 & $\diamond$ & & $\diamond$ & \\
\hline 29 & 3338 & $\diamond$ & & $\diamond$ & \\
\hline 30 & 3340 & $\diamond$ & $\diamond$ & $\diamond$ & \\
\hline
\end{tabular}

Fig. 7 shows the vertical distribution of the three identified microfacies types along the Sargelu Formation in the studied well Tq-1.

\section{Hydrocarbon Potential of the Sargelu Formation}

An evaluation has been carried out for the Sargelu Formation as a source rock at the Tq-1 well, based on the analysis results of Rock-Eval Pyrolysis of 24 samples (Table 3). Different cross-plots and diagrams are used to show the relationship between the parameters obtained from the pyrolysis data in order to define the quantity, quality, maturity and potentiality of the analyzed organic matter of the studied Sargelu Formation in the well Tq-1. The weight percentage of Total Organic Carbon (TOC \%) represents the quantity of organic matter within each analyzed sample. 
According to Tissot and Welte (1978), a minimum value of $0.5 \%$ of organic matter is required for detrital rocks to be considered as source rocks (Table 4) (some laboratories prefer a limit of $1.0 \%$ for the same type of rocks), though $0.3 \%$ TOC is enough for carbonate and evaporite source rocks based on a conclusion drawn by Tissot and Welte (1978), based on the study of Gehman (1962). It is important to mention that such minimum percentages of TOC are required as initial organic matter quantities for the source rocks to expel hydrocarbons during early maturation stages.

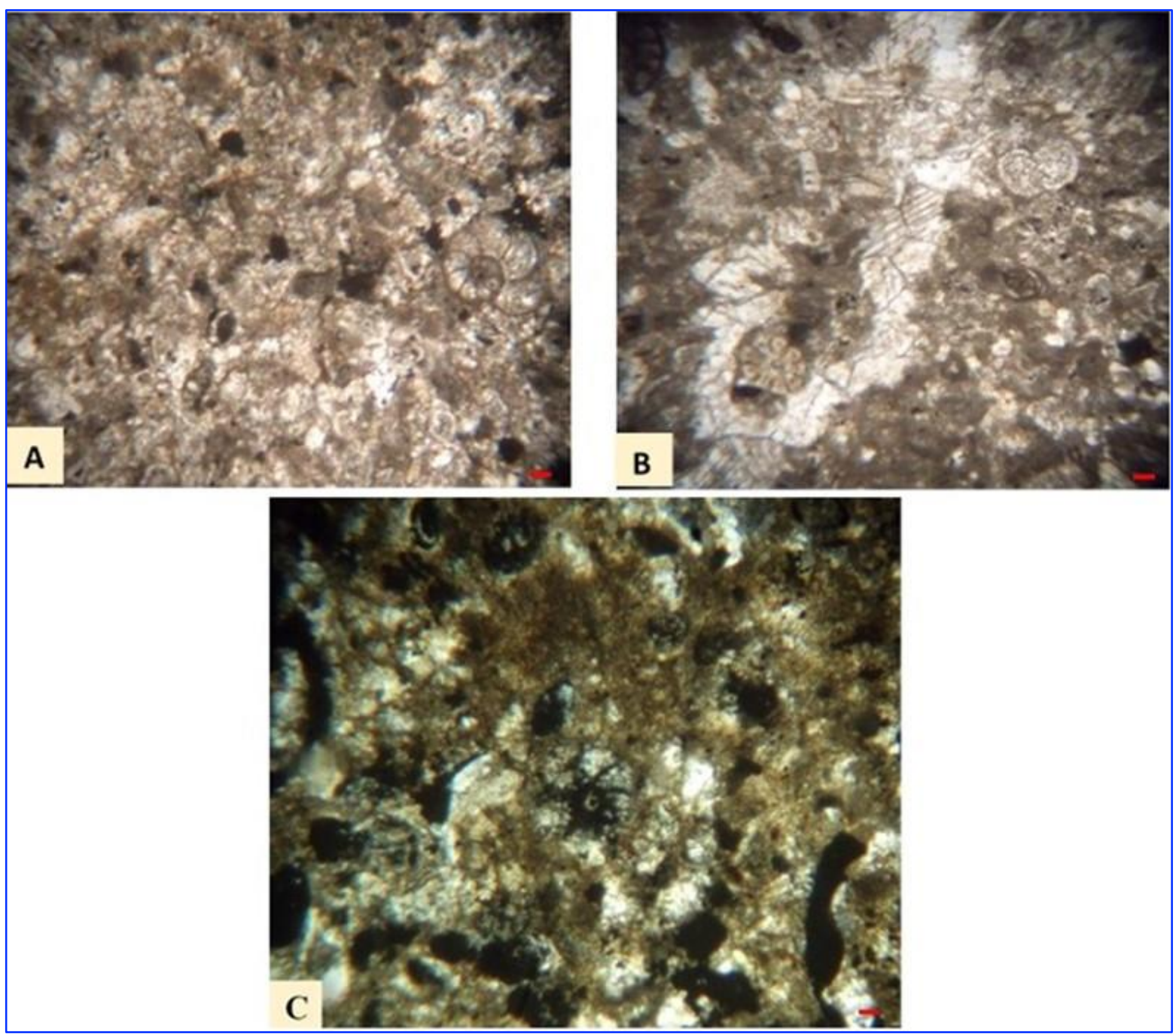

Fig. 4. A) Foraminiferal packstone/ grainstone microfacies, Depth 3245 m; B) Fossiliferous packstone microfacies, Depth 3270 m; C: Foraminiferal wackestone, Depth $3290 \mathrm{~m}$. The scale bar is equal to 50 micrometers $(50 \mu \mathrm{m})$

The TOC values for the analyzed samples of the Sargelu Formation in well Tq-1 ranged between $0.77 \%$ and $11.12 \%$, with an average of $3.03 \%$ (Table 3). Accordingly, the Sargelu Formation can be considered as a very good source rock (Table 4) from a quantity of organic matter perspective (in either the current mature state of the formation or during its immature state). The distribution of the organic matter along the studied section (Fig.8) ranges between good and very good, except at two depth intervals (3,245 $\mathrm{m}$ and 3,280 $\mathrm{m}$ ) where excellent TOC contents were recorded (Fig.8). Plotting HI versus OI on a Van-Krevelen diagram is considered one of the best methods for assessing the kerogen type. By applying this method to the analyzed samples (Fig.9), it is likely that the Sargelu kerogen types are mostly types III and IV which are mostly gas prone kerogen types. 


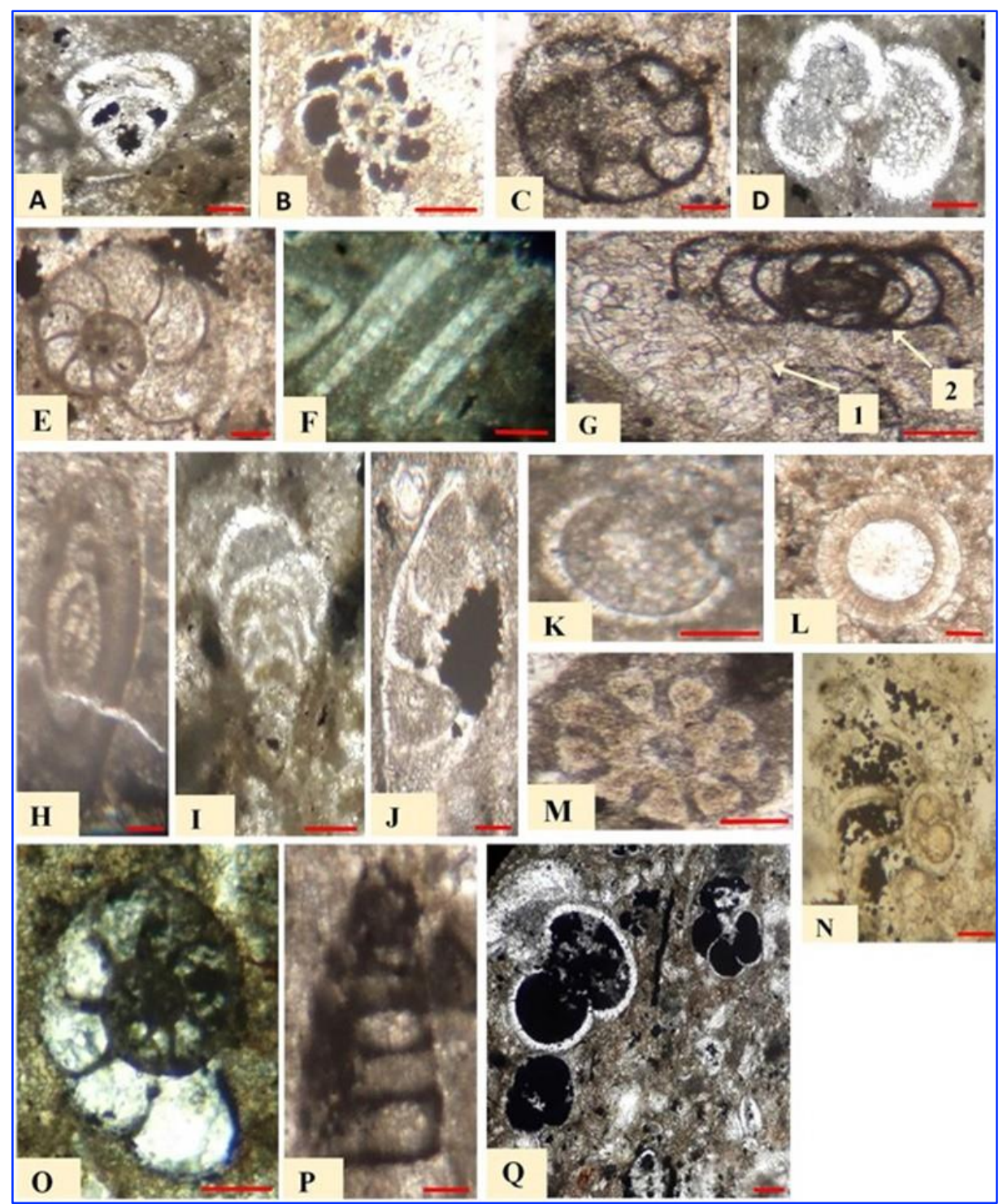

Fig. 5. A: Siphovalvulina variabilis Septfontaine, 1988, Sample no.2, Depth 3245m, oblique section; B: Epistomina sp. Loeblich and Tappan, 1964, impregnated with bitumen, Sample no.2, Depth 3245m; C: Bosniella oenensis Gusic, 1977, Sample no.2, Depth 3245m; D:Siphovalvulina sp. Septfontaine, 1988, Sample no.2, Depth 3245m, transverse section; E: Lenticulina muensteri Roemer, 1839, Sample no.2, Depth 3245m; F: Nipponophycus ramosus Yabe and Toyama, 1928, Sample no.2, Depth 3245m; G: 1. Meandrovoluta asiagoensis Fugagnoli and Rettori, 2003, Sample no.2, Depth 3245m, axial section. 2. Pseudocyclammina sp. Yabe and Hanzawa, 1926, Sample no.2, Depth 3245m; H: Ophthalmidium strumosum Gümbel, 1862, Sample no.2, Depth 3245m; I: Remondoides lugeoni Septfontaine, 1977, Sample no.2, Depth 3245m; J: Lenticulina sp. Lamarck, 1804, Sample no.7, Depth 3270m; K: Permocalculus sp. Elliot, 1955, Sample no.7, Depth 3270m, transverse-oblique section; L: Nipponophycus ramosus Yabe and Toyama, 1928, Sample no.7, Depth 3270m, transverse section; M: Radiolarian spine, Sample no.7, depth 3270m; N: Lenticulina sp. Lamarck, 1804, Sample no.14, Depth 3303m; O: Phenacophragma assurgens Applin, Leoblich and Tappan, 1950, Sample no.16, Depth 3307m, equatorial section; P: Siphovalvulina colomi BouDagher-Fadel et al., 2001, Sample no.21, Depth 3311m; Q: Bitumen filled fossils, Sample no.21, Depth $3311 \mathrm{~m}$. The scale bar is equal to 50 micrometers $(50 \mu \mathrm{m})$ 


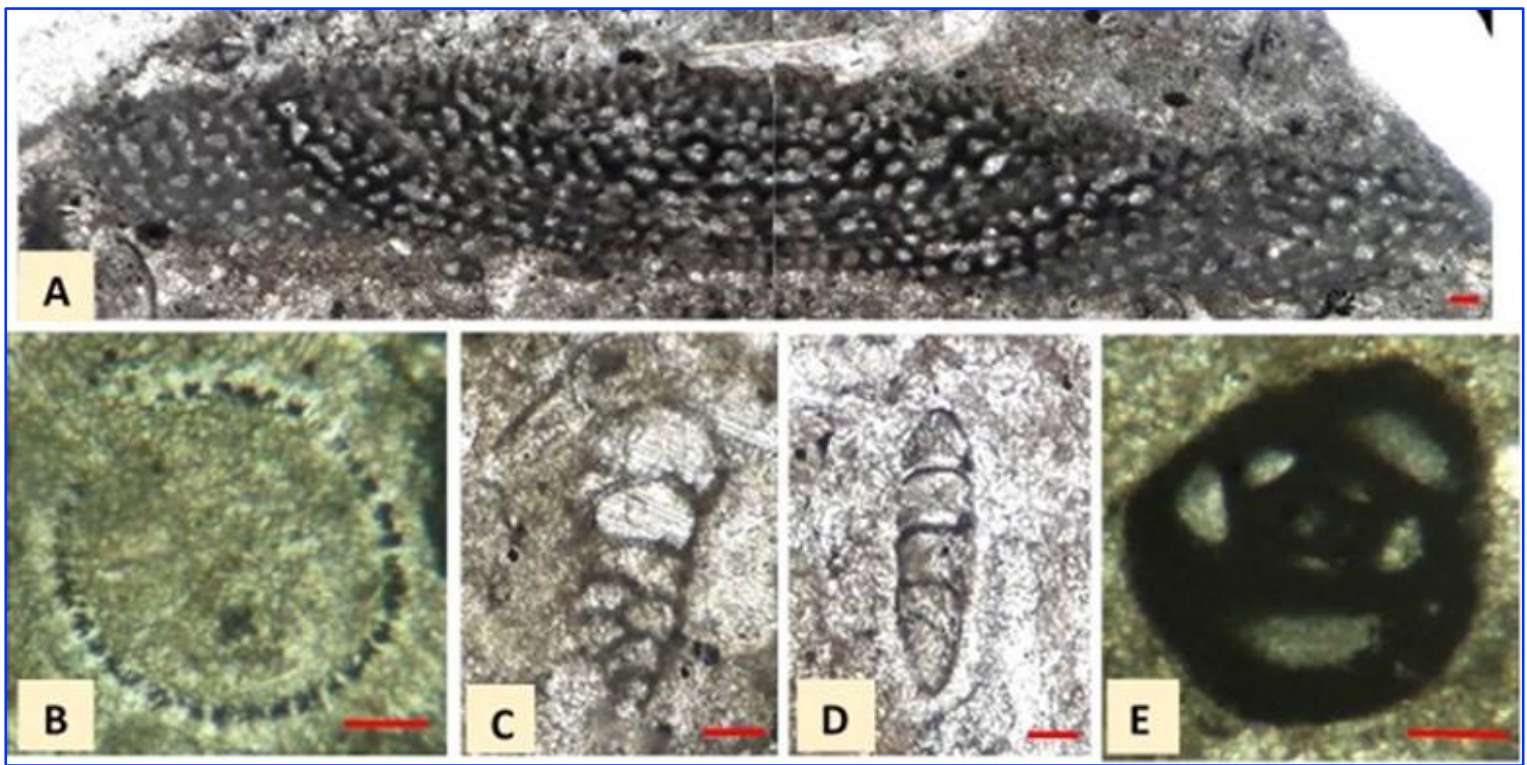

Fig.6. A) Orbitopsella primaeva Henson, 1948, Sample no.24, Depth 3322m, transverse-oblique section; B: Permocalculus sp. Elliot, 1955, Sample no.28, Depth 3333m, transverse section; C: Haghimashella arcuata Häusler, 1890, Sample no.28, Depth 3333m; D: Praepeneroplis senoniensis Hofker, 1949, Sample no.31, Depth 3340m, lateral view; E: Quinqueloculina sp. d'Orbigny, 1826, Sample no.31, Depth $3340 \mathrm{~m}$. The scale bar is equal to 50 micrometers $(50 \mu \mathrm{m})$

All the analyzed samples are currently at a high thermal maturity stage that makes the origin of kerogen unrecognizable. However, the kerogen starting maturity trend can still be detected. Accordingly, the hydrocarbons expected to have been generated from the Sargelu Formation in the study area were mainly gas. To support the detected kerogen type, a cross-plot of S2 versus TOC\% as a function of Hydrogen Index (HI) is established (eg. Akinula et al. 2005) (Fig.10). The majority of the analyzed samples showed $\mathrm{HI}<50 \mathrm{mgHC} / \mathrm{gmTOC}$ and $\mathrm{S} 2$ values $<2 \mathrm{mgHC} /$ gm rock, kerogen types III and IV gas prone look to be the dominant kerogen type in the analyzed samples. Another method to estimate kerogen types and their hydrocarbon potentiality is the Pyrolyzable Carbon Index (PCI), which can be defined as the capability of a sample to generate the highest quantity of hydrocarbon during pyrolysis analysis and is mathematically expressed as $\mathrm{PCI}=0.83^{*} \mathrm{PP}$.

According to this method, a PCI value $\geq 75$ specifies type I kerogen, values between 40 and 50 indicate type II kerogen, and $<15$ represents kerogen type III (Shaaban et al., 2006). From the cross-plot of PCI and TOC\% (Fig.11), all the analyzed samples from the Sargelu Formation appeared to be of kerogen type III. The latter, supports the same previous conclusion of HI versus OI cross plot. In order to assess the generation potential of the Sargelu Formation for hydrocarbons, cross plot between the TOC and the petroleum (genetic) potential was established (eg. Alauge et al., 2014) (Figure 12). Such a generation potential currently ranges between poor and good, with most of the samples having poor potentiality ( $\mathrm{PP}<2.0 \mathrm{mgHC} / \mathrm{gm}$ rock). One sample at a depth of 3,245 m exceptionally showed a very good potentiality (> $7.0 \mathrm{mgHC} / \mathrm{gm}$ rock). An additional way was used (Othman, 2003) to assess the generation potential of the analyzed samples as cross plot between the pyrolysis parameter S2 (i.e. the quantity of hydrocarbons artificially generated from the kerogen remaining within the analyzed sample) and TOC\% values (Fig. 13). The latter showed that the remaining potentiality of the analyzed samples of the Sargelu Formation at well Tq-1 is very low. As a result, it can be considered as having poor potentiality for hydrocarbon generation. 


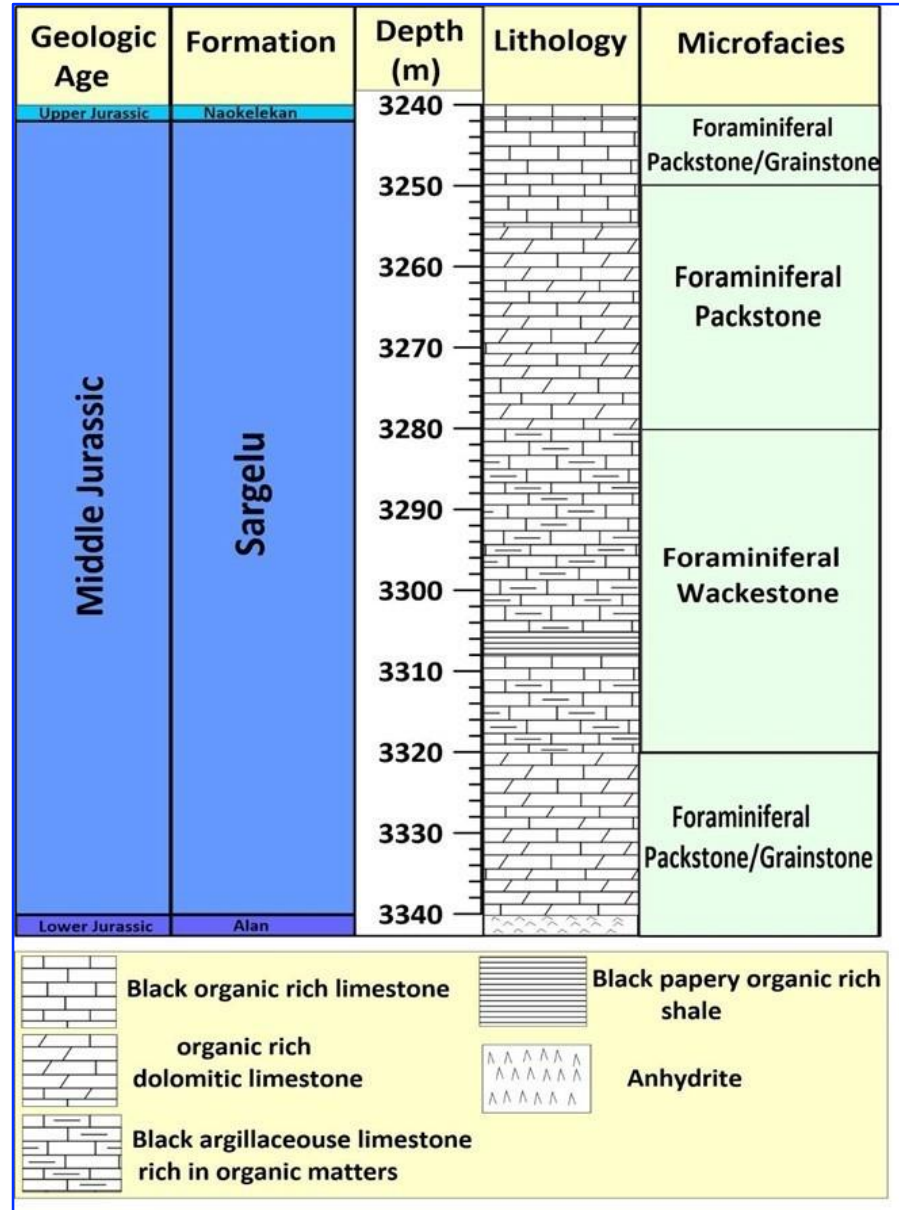

Fig.7. The vertical distribution of microfacies for the Sargelu Formation in the studied well Tq-1

Table 3. Rock-Eval analysis results for the pyrolyzed samples of the Sargelu Formation in well Tq-1

\begin{tabular}{|c|c|c|c|c|c|c|c|c|c|c|c|c|c|c|}
\hline $\begin{array}{l}\text { Depth } \\
\text { m }\end{array}$ & $\begin{array}{l}\text { Qty. } \\
\text { mg }\end{array}$ & $\begin{array}{l}\text { TOC } \\
\text { wt } \%\end{array}$ & $\begin{array}{c}\text { S1 } \\
\text { mgHC/ } \\
\text { grock }\end{array}$ & $\begin{array}{c}\text { S2 } \\
\text { mgHC/ } \\
\text { grock }\end{array}$ & $\begin{array}{c}\mathbf{S 3} \\
\mathrm{mgCo} / \\
\text { grock }\end{array}$ & $\underset{{ }^{\circ} \mathrm{C}}{\mathbf{T}_{\max }}$ & $\begin{array}{c}\text { HI } \\
\text { mgHC/ } \\
\text { gTOC }\end{array}$ & $\begin{array}{c}\text { OI } \\
\text { mgCo } \\
\text { /gTOC }\end{array}$ & $\begin{array}{c}\mathbf{P P} \\
\mathrm{mgHCl} \\
\text { grock }\end{array}$ & PI & $\begin{array}{c}\text { MINC }^{*} \\
\text { wt } \%\end{array}$ & $\begin{array}{c}\mathbf{R C} * * \\
\text { wt } \%\end{array}$ & $\begin{array}{c}\text { S1/ } \\
\text { TOC }\end{array}$ & $\begin{array}{c}\text { PCI } \\
\mathrm{mgHC} / \\
\text { grock }\end{array}$ \\
\hline 3242 & 66.9 & 4 & 3.28 & 1.75 & 0.34 & 470 & 44 & 9 & 5.03 & 0.65 & 8.95 & 3.56 & 0.82 & 4.17 \\
\hline 3245 & 64.4 & 11.12 & 6.66 & 5.22 & 0.48 & 520 & 47 & 4 & 11.88 & 0.56 & 8.01 & 10.08 & 0.60 & 9.86 \\
\hline 3250 & 59.2 & 3.76 & 2.85 & 1.82 & 0.63 & 523 & 48 & 17 & 4.67 & 0.61 & 8.89 & 3.34 & 0.76 & 3.88 \\
\hline 3255 & 59.3 & 3.08 & 2.08 & 1.23 & 0.84 & 510 & 40 & 27 & 3.31 & 0.63 & 6.31 & 2.77 & 0.68 & 2.75 \\
\hline 3260 & 64.4 & 2.2 & 1.93 & 1.13 & 0.57 & 510 & 51 & 26 & 3.06 & 0.63 & 10.26 & 1.92 & 0.88 & 2.54 \\
\hline 3265 & 59.4 & 1.17 & 0.96 & 0.71 & 0.44 & 440 & 61 & 38 & 1.67 & 0.57 & 10.62 & 1.01 & 0.82 & 1.39 \\
\hline 3270 & 59.6 & 0.92 & 1.19 & 0.51 & 0.75 & 480 & 55 & 82 & 1.70 & 0.70 & 8.97 & 0.75 & 1.29 & 1.41 \\
\hline 3275 & 62.5 & 0.77 & 0.74 & 0.59 & 0.23 & 478 & 77 & 30 & 1.33 & 0.56 & 8.41 & 0.65 & 0.96 & 1.10 \\
\hline 3280 & 63.8 & 6.33 & 3.06 & 2.33 & 0.54 & 522 & 37 & 9 & 5.39 & 0.57 & 7.69 & 5.84 & 0.48 & 4.47 \\
\hline 3285 & 60.5 & 3.13 & 2.38 & 1.17 & 0.92 & 473 & 37 & 29 & 3.55 & 0.67 & 9.51 & 2.8 & 0.76 & 2.95 \\
\hline 3290 & 62 & 3.18 & 1.42 & 1.21 & 0.75 & 482 & 38 & 24 & 2.63 & 0.54 & 6.61 & 2.93 & 0.45 & 2.18 \\
\hline 3295 & 61.5 & 2.9 & 2.12 & 1.5 & 0.44 & 475 & 52 & 15 & 3.62 & 0.59 & 7.73 & 2.57 & 0.73 & 3.00 \\
\hline 3300 & 66.7 & 3.41 & 1.52 & 1.48 & 0.28 & 480 & 43 & 8 & 3.00 & 0.51 & 6.12 & 3.14 & 0.45 & 2.49 \\
\hline 3305 & 67.5 & 2.43 & 0.07 & 0.17 & 0.23 & 448 & 7 & 9 & 0.24 & 0.29 & 1.14 & 2.4 & 0.03 & 0.20 \\
\hline 3307 & 66.4 & 4.17 & 0.15 & 0.15 & 0.32 & 535 & 4 & 8 & 0.30 & 0.50 & 1.13 & 4.13 & 0.04 & 0.25 \\
\hline 3308 & 61 & 2.5 & 0.72 & 0.38 & 0.17 & 452 & 15 & 7 & 1.10 & 0.65 & 1.42 & 2.4 & 0.29 & 0.91 \\
\hline 3309 & 68.4 & 1.01 & 0.15 & 0.06 & 0.33 & 463 & 6 & 33 & 0.21 & 0.71 & 9.09 & 0.98 & 0.15 & 0.17 \\
\hline 3315 & 63 & 2.11 & 0.9 & 0.85 & 0.41 & 478 & 40 & 19 & 1.75 & 0.51 & 7.83 & 1.94 & 0.43 & 1.45 \\
\hline 3320 & 64.4 & 2.74 & 0.46 & 0.24 & 0.39 & 470 & 9 & 14 & 0.70 & 0.66 & 7.36 & 2.66 & 0.17 & 0.58 \\
\hline 3325 & 69 & 3 & 0.14 & 0.11 & 0.35 & 540 & 4 & 12 & 0.25 & 0.56 & 5.41 & 2.96 & 0.05 & 0.21 \\
\hline 3330 & 56 & 3.08 & 0.28 & 0.35 & 0.3 & 510 & 11 & 10 & 0.63 & 0.44 & 1.54 & 3.01 & 0.09 & 0.52 \\
\hline 3335 & 61.3 & 1.34 & 0.16 & 0.08 & 0.34 & 565 & 6 & 25 & 0.24 & 0.67 & 9.53 & 1.31 & 0.12 & 0.20 \\
\hline 3338 & 63.5 & 3.01 & 0.42 & 0.23 & 0.38 & 470 & 8 & 13 & 0.65 & 0.65 & 6 & 2.94 & 0.14 & 0.54 \\
\hline 3340 & 68.8 & 1.46 & 0.22 & 0.37 & 0.3 & 470 & 25 & 21 & 0.59 & 0.37 & 8.45 & 1.4 & 0.15 & 0.49 \\
\hline
\end{tabular}

* Mineral Carbon; **Residual Carbon 
Table 4. Source rock quality classification based on TOCwt\% (after Tissot and Welte, 1978)

\begin{tabular}{cc}
\hline TOC $($ wt $\%)$ & Source rock quality \\
\hline$<0.5$ & Poor \\
$0.5-1$ & Fair \\
$1-2$ & Good \\
$2-4$ & Very good \\
$>4$ & Excellent \\
\hline
\end{tabular}

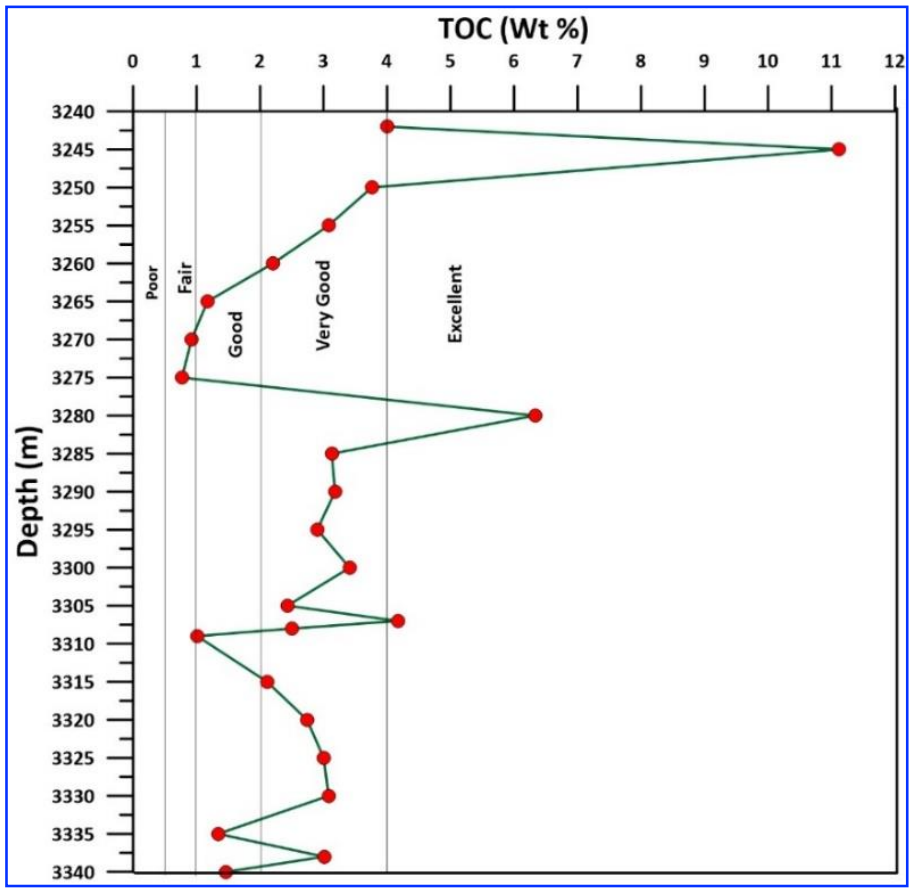

Fig.8. TOC versus depth for the analyzed samples of the Sargelu Formation in well Tq-1

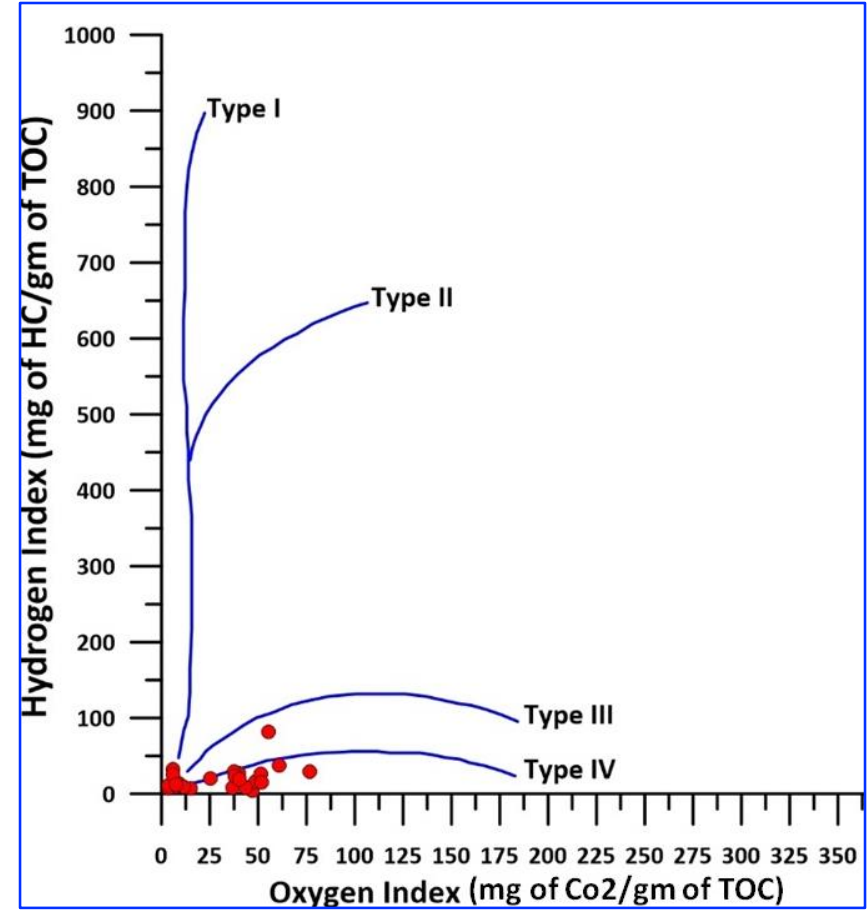

Fig.9. Cross plot of HI versus OI for the Sargelu Formation in well Tq-1(after Espitalie et al. (1977) 


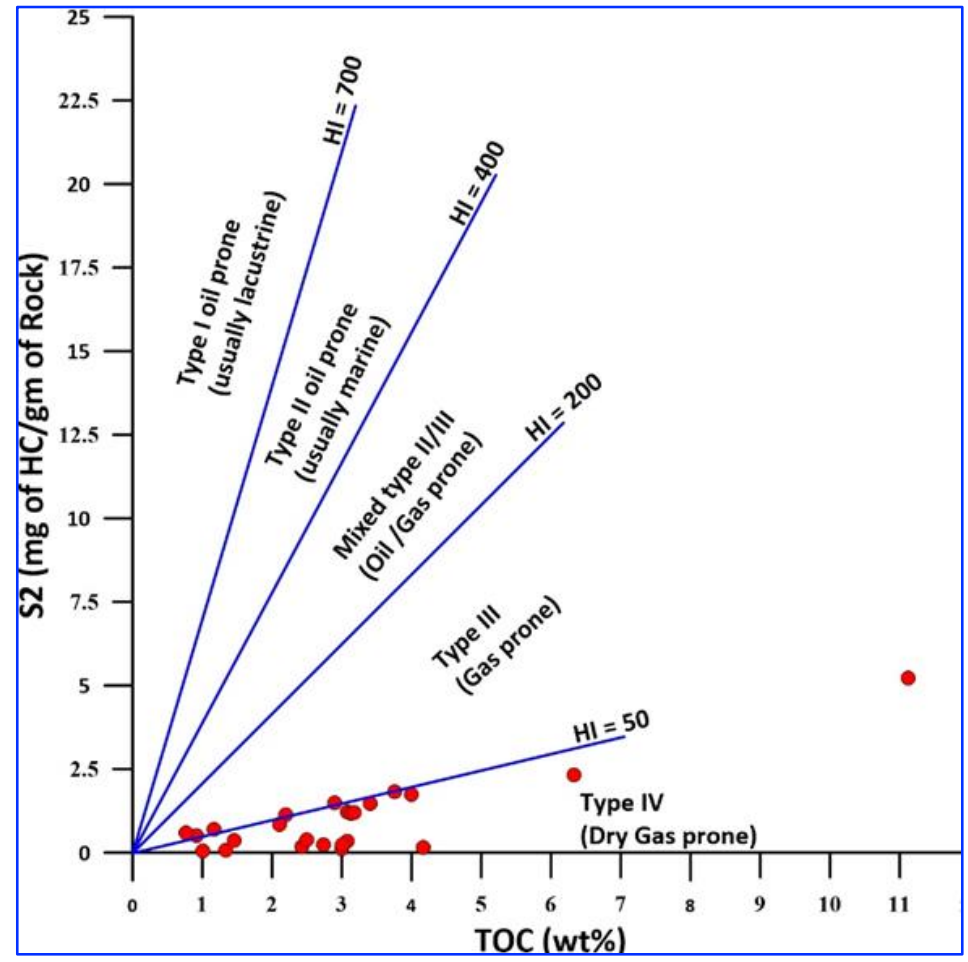

Fig.10. Cross plot of S2 versus TOC\% for the analyzed samples of the Sargelu Formation in well Tq1 (The cross plot is after Akinula et al., 2005)

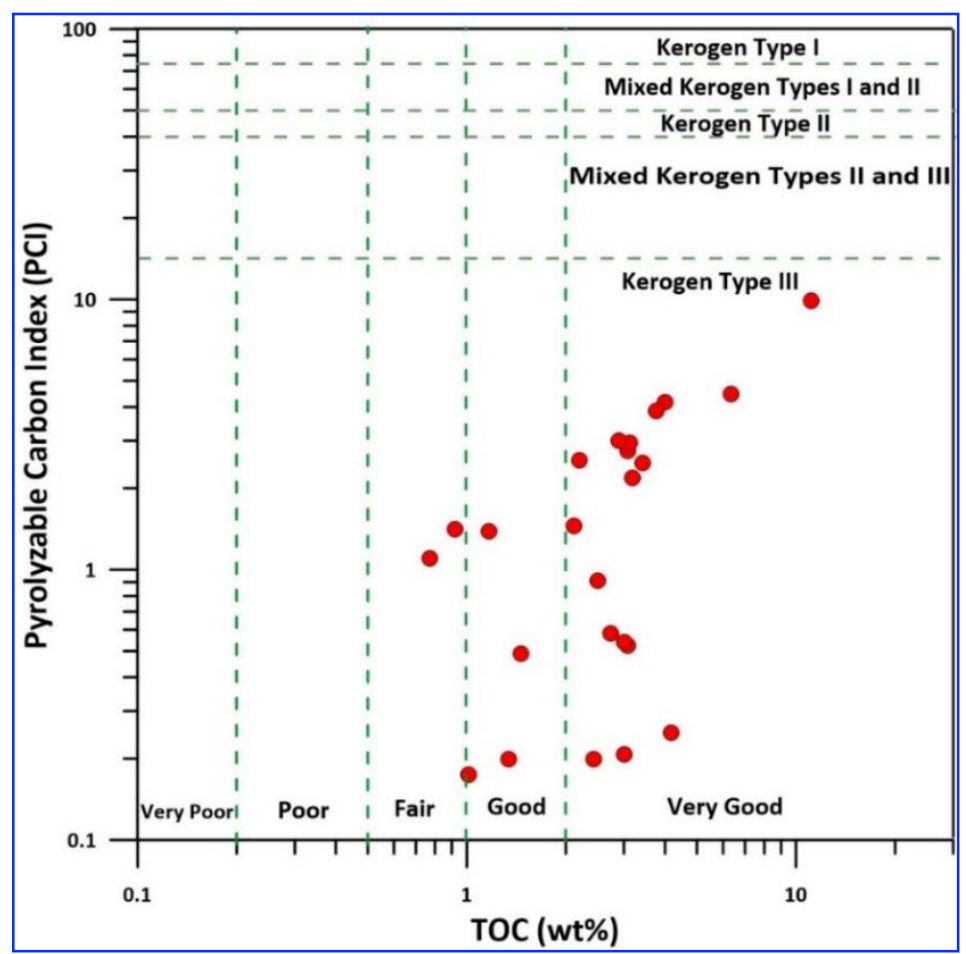

Fig.11. Cross plot of pyrolysable Carbon Index (PCI) versus TOC\% for the analyzed samples of the Sargelu Formation in well Tq-1 


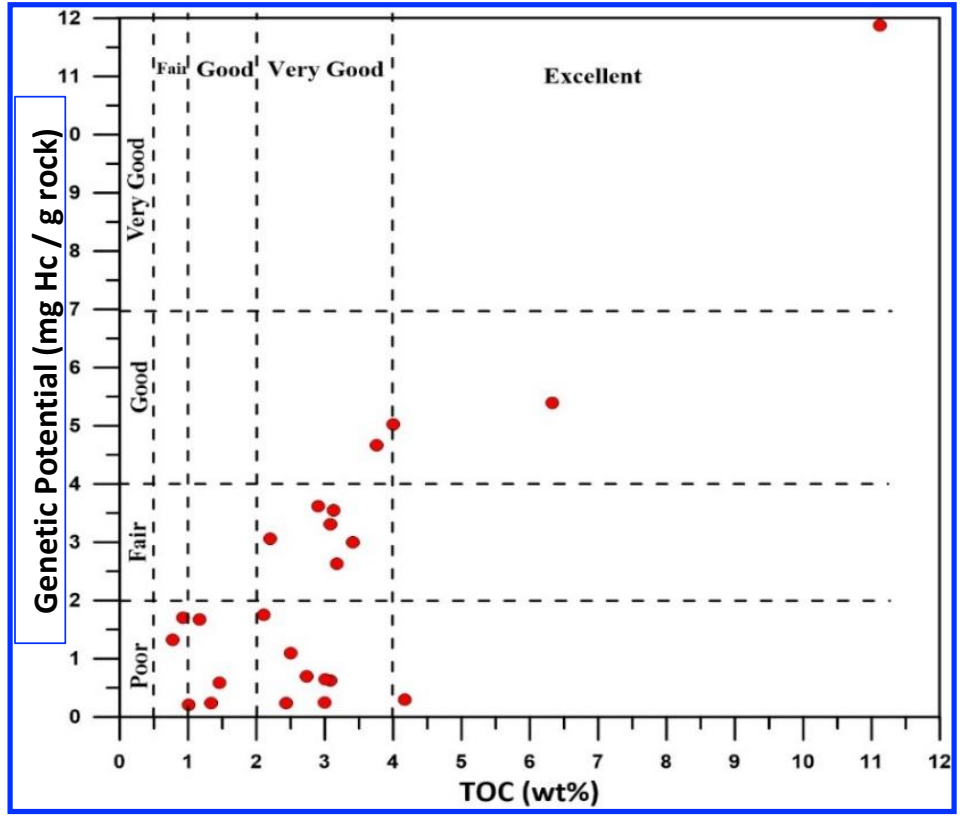

Fig.12. Cross plot of TOC\% versus petroleum (genetic) potential for the analyzed samples of the Sargelu Fromation in well Tq-1

According to Hunt (1996), the depth at which a source rock starts to expel oil is determined by the bitumen index (S1/TOC), which is also called the migration index. Smith (1994; in Hunt, 1996) mentioned that the ratio of S1/TOC should be from $0.1-0.2$ to start oil expulsion from a source rock (Fig.14). When S1 is high and TOC is low, migrated hydrocarbons are pointed out. Plotting depth versus S1/TOC (Fig.14) for the analyzed samples showed that except four samples at depths $3,305 \mathrm{~m}, 3,307 \mathrm{~m}$, $3,325 \mathrm{~m}$, and 3,330m, all other samples have S1/TOC values between 0.1 and 0.2 or higher. The organic matter within these four mentioned samples look to have an inert origin, as comprises thermally mature samples, and their TOC values are relatively high, while the quantity of hydrocarbons generated (S1) is low. Accordingly and before concluding that the Sargelu Formation in most of its parts can generate and expel hydrocarbons, it's important to be sure about the indigeneity of the existed hydrocarbons within the analyzed samples, especially those samples that showed high $\mathrm{S} 1$ values.

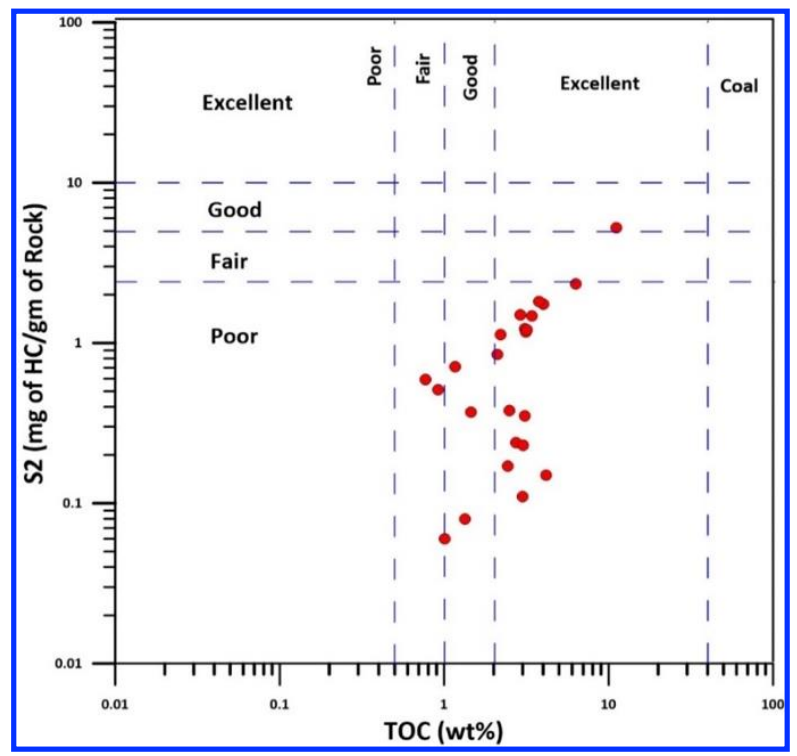

Fig.13. Cross plot of $\mathrm{S} 2$ versus TOC\% for the analyzed samples of the Sargelu Formation in well Tq-1. 


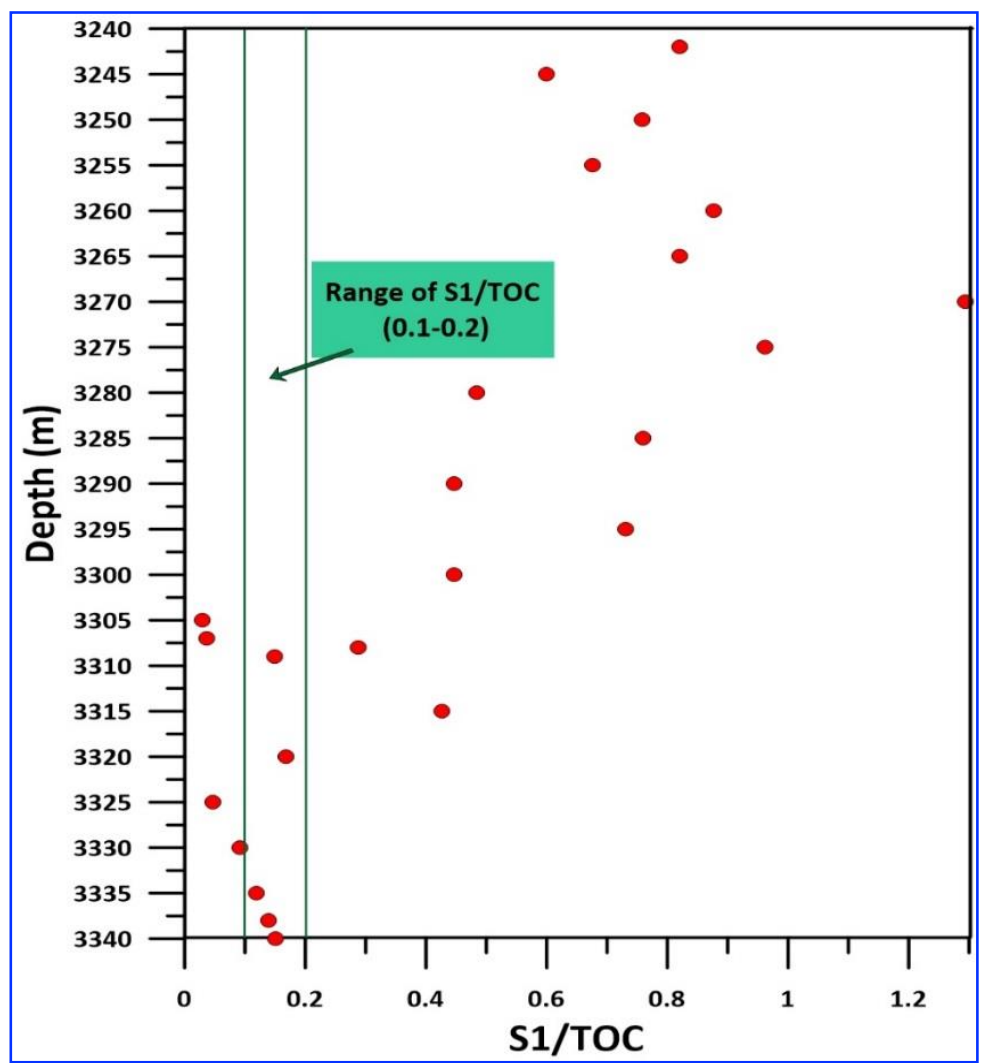

Fig.14. Cross plot of depth versus S1/TOC for the analyzed samples of the Sargelu Formation in well Tq-1

The cross plot of S1 versus TOC\% (Fig.15) is typically used to differentiate between migrated hydrocarbons and contaminants from indigenous hydrocarbons (e.g. Hunt, 1996). All the analyzed samples showed reasonable S1 to TOC values indicating they contained indigenous hydrocarbons with no contamination or migrated hydrocarbon effects.

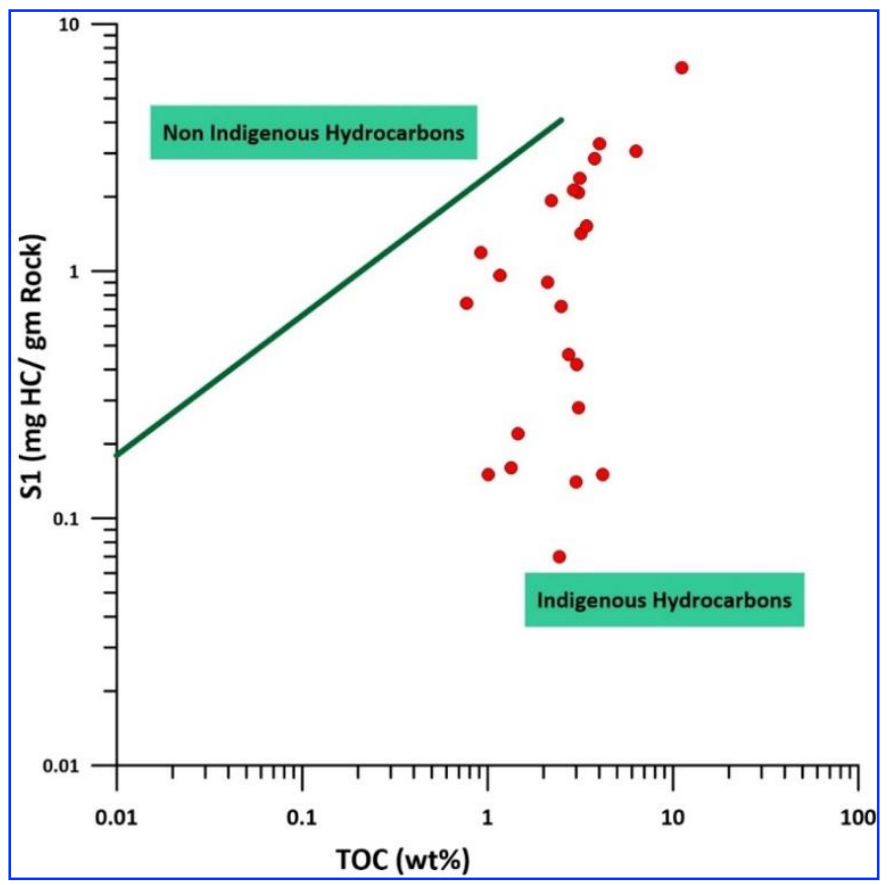

Fig.15. Cross plot of S1 versus TOC\% for the analyzed samples of the Sargelu Formation in well Tq-1. 
Residual Carbon (RC), according to Johannes et al. (2006), is the quantity of organic carbon in wt $\%$ gained from $\mathrm{CO}$ and $\mathrm{CO} 2$ throughout the pyrolysis process, or the proportion of TOC which represents non-hydrolysable organic carbon $\left(\mathrm{RC}=\mathrm{RC} \mathrm{CO}+\mathrm{RC} \mathrm{CO}_{2}=\mathrm{TOC}-\mathrm{PC}\right)$. The cross plot of TOC\% against RC (Fig.16) shows that TOC values are almost equal to RC values for the majority of the analyzed samples indicating too little generative potential remaining in the samples (e.g. English et al. 2004). Thus, at present, the Sargelu Formation has low potentiality for generating hydrocarbons in the Taq Taq Field. However, in the paleo-time it should have generated a good number of hydrocarbons. English et al. (2015) and Pitman et al. (2004) mentioned that the Sargelu and Naokelekan formations started generating oil since Late Cretaceous in Khashim al-Ahmer Field (Mesopotamian Foredeep) and since Early Miocene in Baba Dome of the Kirkuk Field (Zagros Fold Belt).

According to the Basin Modeling simulation, Hakimi et al. (2018) concluded that the Sargelu Formation started generating hydrocarbons since Paleocene in the Taq Taq Field (Zagros Fold Belt) and currently is at the late stages of oil generation. Whereas in Ajeel Field (Mesopotamian Foredeep), the Sargelu Formation entered the realm of oil generation during Eocene and currently is at the peak oil generation stage. Accordingly, the result of this study in confirms the conclusion of the 1D basin modeling of Hakimi et al. (2018) that the Sargelu Formation is currently in an advanced stage of thermal maturation (i.e. near the end of the oil generation stage).

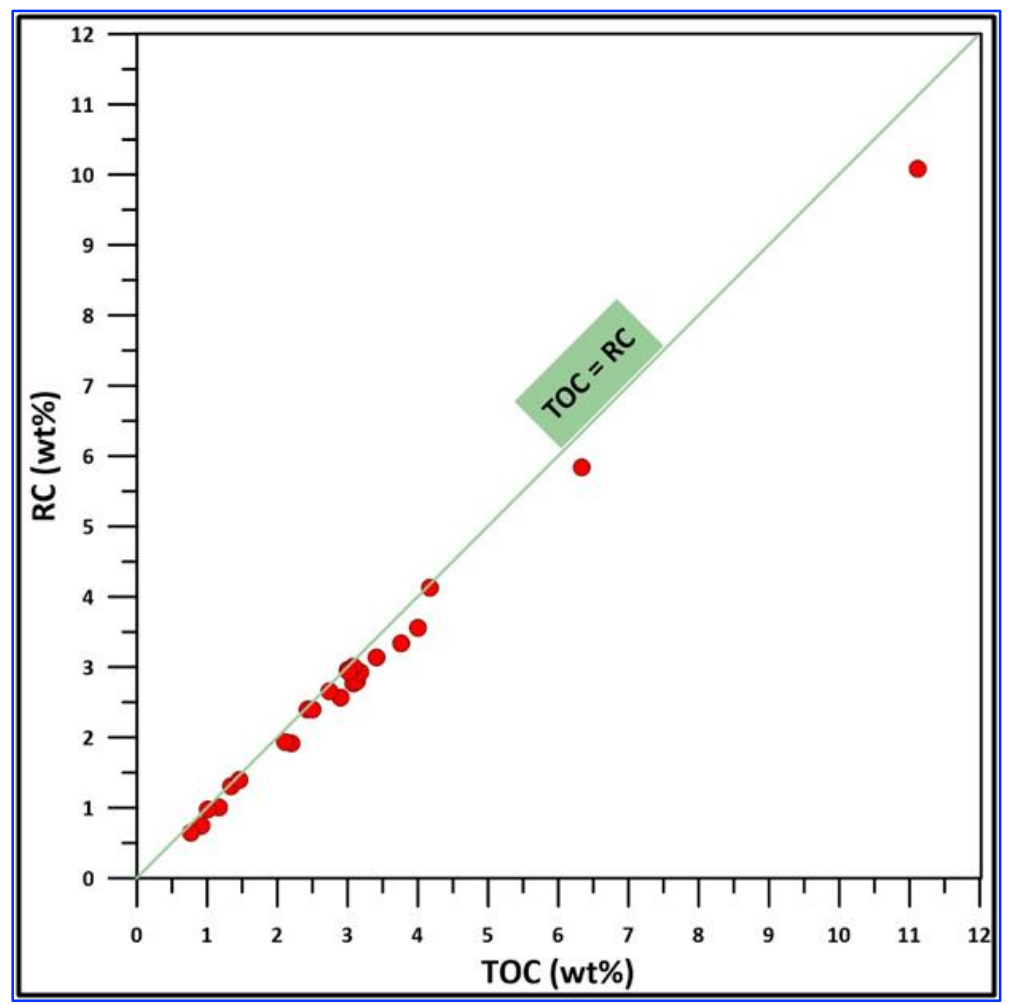

Fig.16. Cross plot of RC\% versus TOC\% for the analyzed samples of the Sargelu Formation in well Tq-1

One of the most important tasks in source rock evaluation is an organic matter maturity assessment. The thermal maturity stages of source rocks can be determined through different techniques, such as elemental analysis, pyrolysis, Gas Chromatography (GC), and Apatite Fission Tracks (AFT), or optically, using Vitrinite Reflectance (Ro\%) or Thermal Alteration Index (TAI) methods.

Tmax value obtained from pyrolysis analysis represents the highest temperature that is achieved when converting remaining kerogen in the analyzed sample to gas (temperature at the peak of the S2 curve) which is considered a maturity indicator for the analyzed sample. Production Index (PI) is also among the maturity parameters of pyrolysis analysis that represents the ratio of generated hydrocarbons 
to the petroleum potentiality of rock and is a function of the stage of catagenesis actually realized by the analyzed sample. During the maturation process, different kerogen types show different Tmax responses. For kerogen types II and III, Tmax is a good maturity indicator, but not for type I, because Tmax remains constant as a function of maturity (Tissot et al., 1987; in Whelan and Thompson-Rizer, 1993). Bacon et al. (2000) proposed many values relating to the level of maturity of the "oil window" depending on the organic matter type, Tmax, and PI (Table 5). As the organic matter within the studied samples appeared to be mainly of kerogen type III, the threshold of maturity is expected to be around $440 C^{\circ}$, with PI equal to about 0.15 .

Table 5. Maturation level as a function of production index and Tmax for different kerogen types (after Bacon et al., 2000)

\begin{tabular}{|c|c|c|c|c|}
\hline $\begin{array}{l}\text { Maturation } \\
\text { Level }\end{array}$ & $\begin{array}{c}\text { Production Index } \\
\text { (PI) }\end{array}$ & $\begin{array}{c}\mathbf{T}_{\max } \text { for } \\
\text { Type I }\left(\mathbf{C}^{\circ}\right)\end{array}$ & $\begin{array}{c}\mathbf{T}_{\max } \text { for } \\
\text { Type II }\left(\mathbf{C}^{\circ}\right)\end{array}$ & $\begin{array}{c}\mathbf{T}_{\max } \text { for } \\
\text { Type III }\left(\mathbf{C}^{\circ}\right)\end{array}$ \\
\hline Immature & $0.15<$ & $<445$ & $<435$ & $<440$ \\
\hline Mature & $0.15-0.4$ & $445-455$ & $435-460$ & $440-470$ \\
\hline Over mature & $>0.4$ & $>445$ & $>460$ & $>470$ \\
\hline
\end{tabular}

Fig.17. shows the maturity of the Sargelu Formation in the studied well, depending on PI and Tmax values obtained as a function of depth. It is clear from Figure 17 that the whole formation can currently be considered thermally at the post (over) mature stage. Minor differences between the determined maturity stages of some analyzed samples using PI and Tmax values with PI showing higher maturity can be interpreted as a possible effect of contamination. To better show the maturity state of the studied Sargelu Formation, PI and Tmax parameters were cross plotted, as recommended by Espitalli et al. (1977; in Katz, 2001), adapting their diagram that functions for the source rocks containing mostly type III kerogen (Fig.18). Fig.18 shows that most of the analyzed samples are thermally at the postmature stage. Also, it is important to mention that three of the analyzed samples at depths 3,265 m, 3,308 $\mathrm{m}$, and 3,309 $\mathrm{m}$ in contrary to the results obtained from Fig. 15 showed a slight effect of contamination. This is indicated by their PI values, which are higher than they should be at their measured Tmax. Finally, it is important to note that Odisho and Othman (1992) studied a rock sample at depth of 3,308 $\mathrm{m}$ of the Sargelu Formation in well Tq-1 using a rock eval pyrolysis method, and their results were as follows:

TOC (0.49\%), S1 $(0.06 \mathrm{mg} / \mathrm{g}), \mathrm{S} 2(0.5 \mathrm{mg} / \mathrm{g}), \mathrm{HI}(102)$, PI $(0.11)$, PP $(0.56 \mathrm{mg} / \mathrm{g})$, and Tmax $\left(515^{\circ} \mathrm{C}\right)$. Apart from the probability of technical defects during the pyrolysis analysis, the low TOC value obtained by Odisho and Othman (1992) could have influenced the other pyrolysis parameter values such as PI, which indicates early maturity state in their results, whereas the high Tmax value contractively indicates a very advanced maturity stage (post-mature).

\section{Palynological Analysis}

Palynological slides were prepared for the study samples following the conventional procedure of using $\mathrm{HCl}$ acid to remove carbonate materials and $\mathrm{HF}$ acid to remove silicates from the samples. The slides were studied optically using transmitted light microscopy to identify components of the extracted organic matters. The palynological analysis showed that the Amorphous Organic Matters (AOM) are the dominant component of all 18 analyzed samples with $\geq 70 \%$ content. 


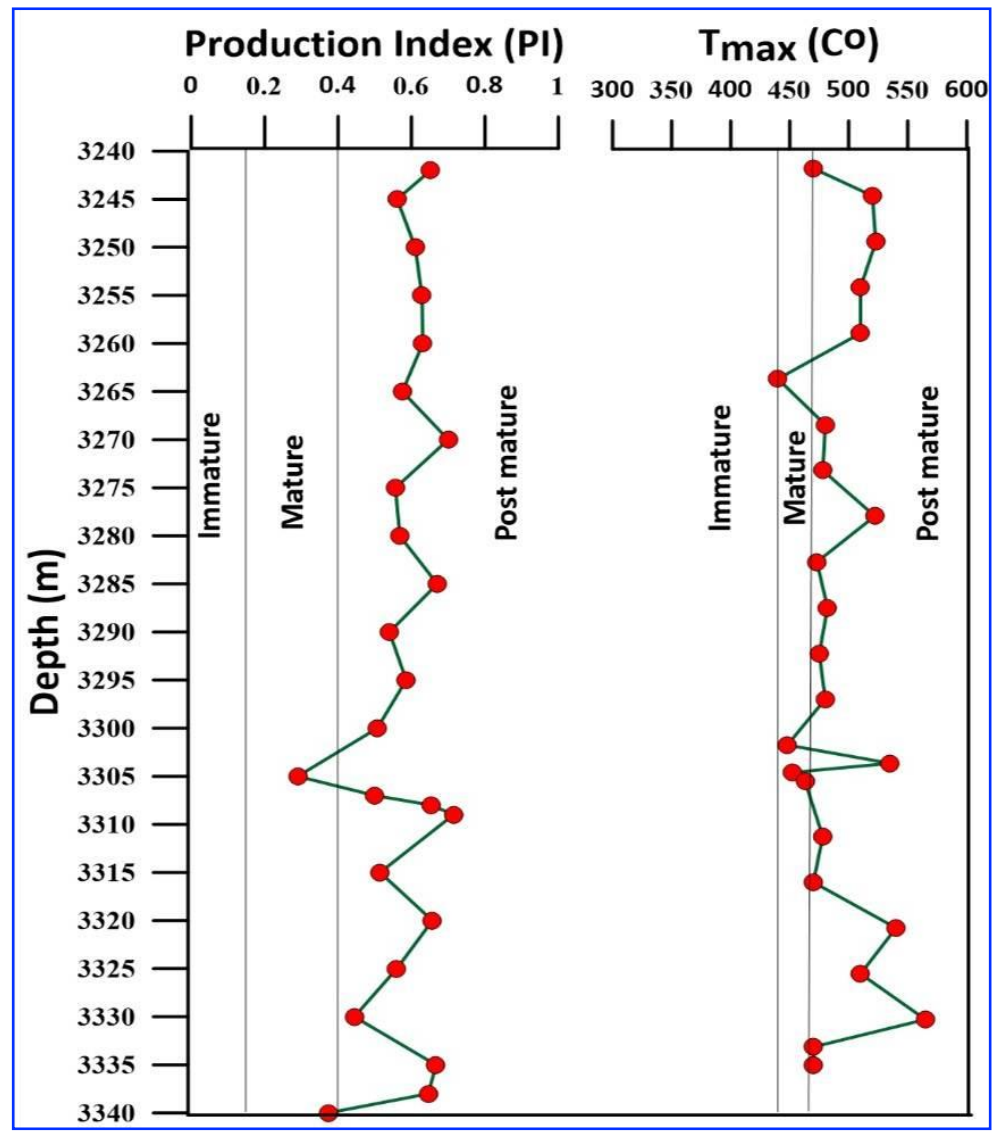

Fig.17. Production Index and $\mathrm{T}_{\max }$ for the analyzed samples of the Sargelu Formation along the well Tq-1

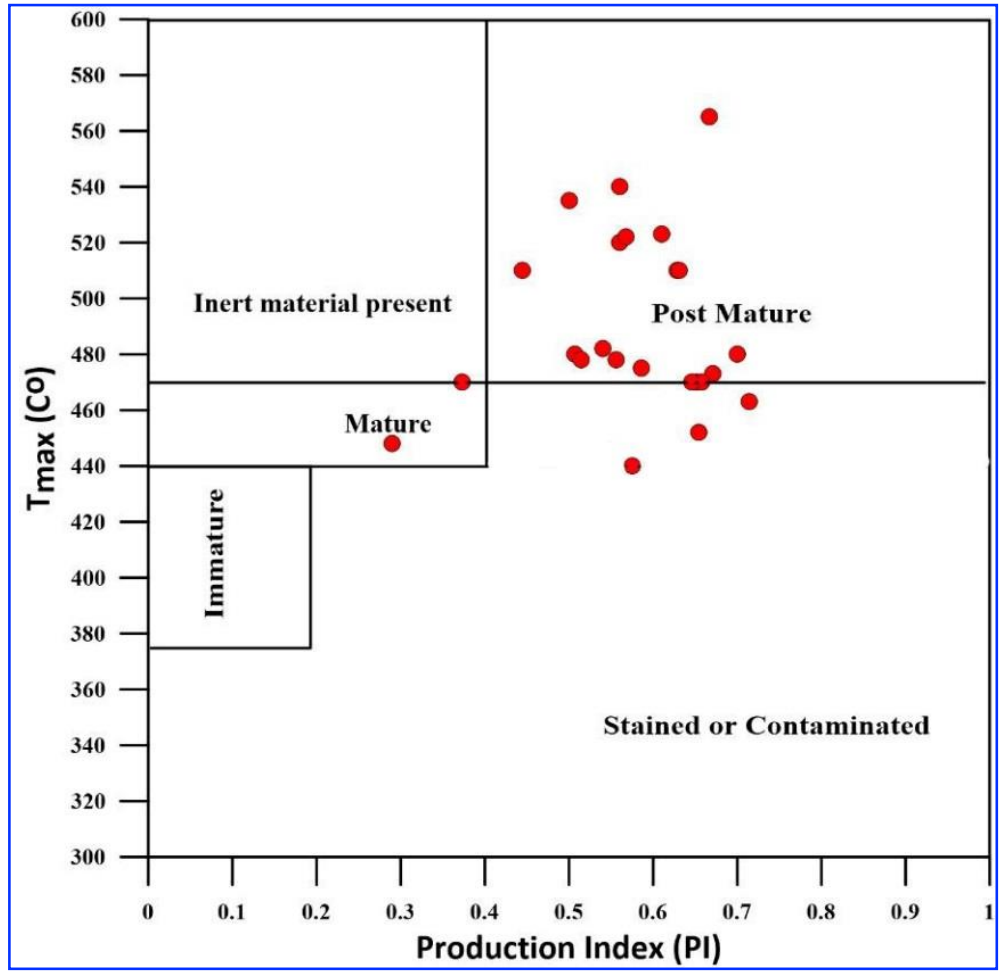

Fig.18. Cross plot of Tmax versus PI plot for the analyzed samples of the Sargelu Formation in well Tq-1using the diagram of Espitalli et al. (1977) 
The AOM appeared in different shapes such as dense particles (Fig. 19A) or thin reticulate shapes (Fig. 19B). The phytoclast formed between $10 \%$ and $25 \%$ of total organic matter components and mainly consisted of wood debris (Figs. 19C and 19D) and different shapes of phytoclast (Fig. 19E) together with opaque materials and foraminifera test linings (Fig. 19F). Palynomorphs comprised the remaining percentage of the components with less than 10\%, and unclear features. Applying the ternary AOMPhytoclast- Palynomorph (APP) proposed by Tyson (1995), the organic matters of the Sargelu Formation are classified in the IX field reflecting distal suboxic-anoxic basinal deposition (Fig.20). The IX field of the mentioned ternary is expected to contain types I and II kerogen (with II $>$ I), and having high oil generation potential. The latter is only considered a right conclusion if the organic matters are at the immature stage or at the diagenesis stage of hydrocarbon generation. As the analyzed samples are at post mature stage, therefore they followed the thermal evolutionary trend towards the field IX of the ternary (Tyson, 1995).

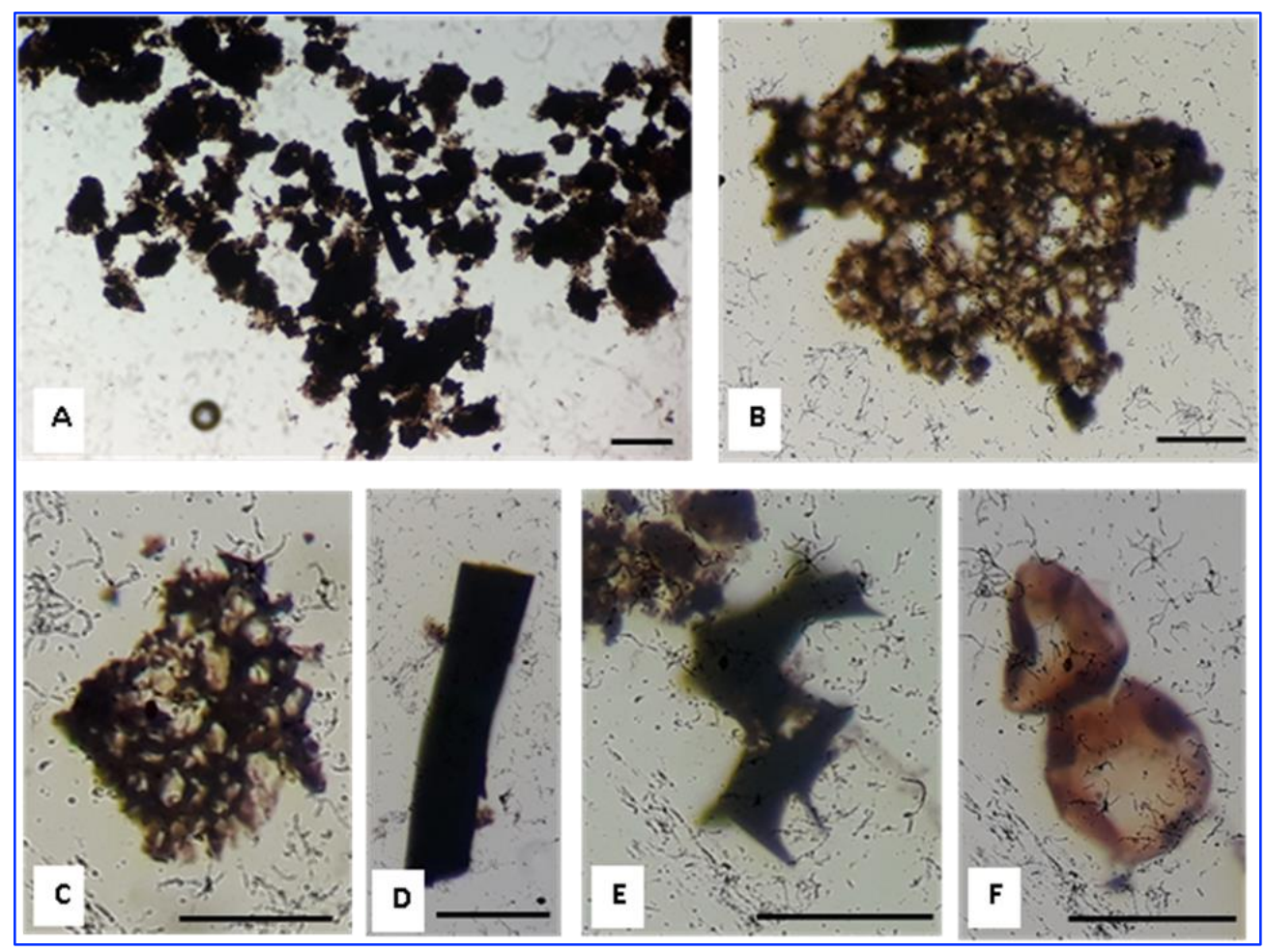

Fig. 19. A) Dense and thick type AOM, Sample no.2, Slide no.2B, Depth $3245 \mathrm{~m}$; B) Reticulate type of AOM, Sample no.5, Slide no.5A, Depth 3260m; C: Unidentified palynomorph, Sample no.2, Slide no.2A, Depth 3245m; D: Wood debris, Sample no.9, Slide no.9B, Depth 3280m; E: Spiny phytoclast, Sample no.23, Slide no23A. Depth 3320m; F: Foraminifera test lining, Sample no.5, Slide no.5B, Depth $3260 \mathrm{~m}$. The scale bar is equal to 100 micrometers $(100 \mu \mathrm{m})$

It is also important to mention that the existing AOM could be mostly due to degradation of initial phytoclast and palynomorphs (Batten, 1996). So, AOM should not necessarily considered as a source only for oil but a source for gas also. Therefore, existence of kerogen III rich of AOM should not be out of expectation.

As no clear and well identified palynomorphs were seen in the examined slides, the color of the AOM relied on detecting the maturation state of the samples optically. According to the thermal color change scale suggested by the Philip Oil Company (Pearson, 1990), the examined organic matters showed color scales ranging between $3+$ and $4-$, indicating organic matters in a thermally mature state and at the end zone of liquid oil generation to the beginning of condensate - wet gas generation. 


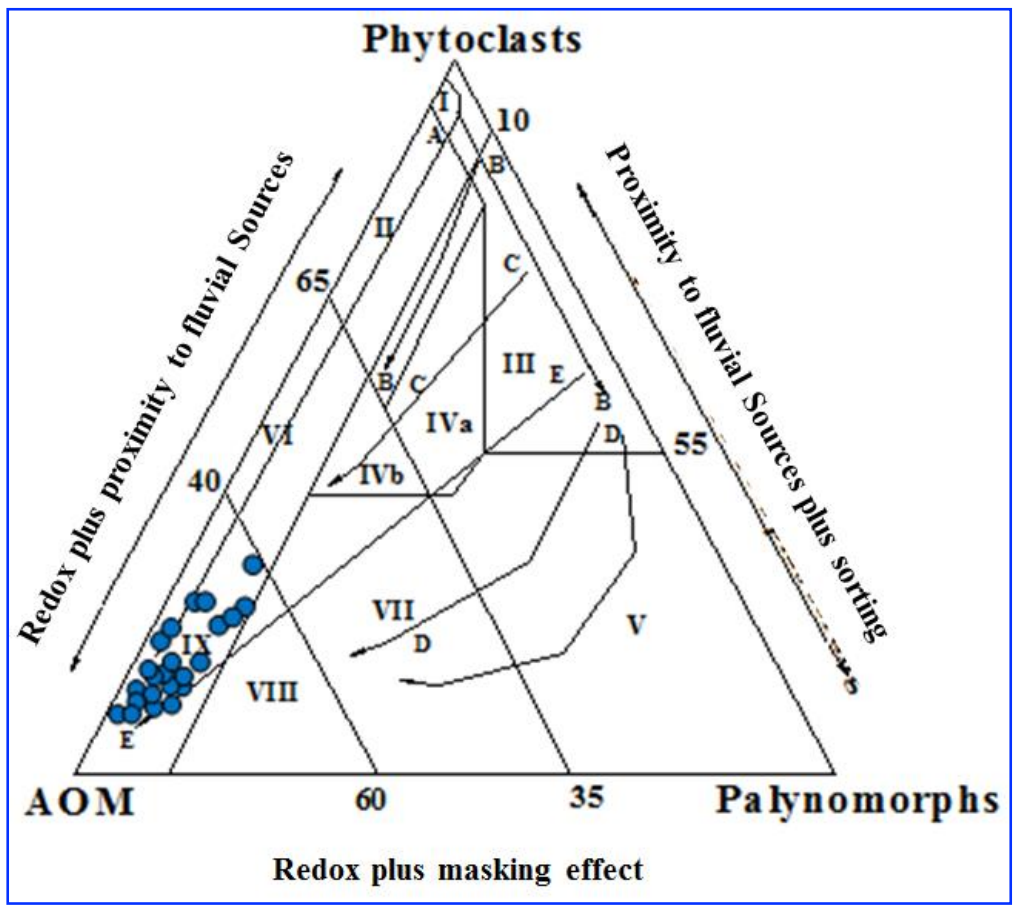

Fig.20. Location of the examined organic matters of the Sargelu Formation in the field IX of the APP ternary of Tyson (1995).

\section{Vitrinite Reflectance and Organic Petrography}

One of the most important tools for determining the thermal maturity level of organic matters in sedimentary rocks is vitrinite reflectance. This technique described for the first time by Marlies Teichmüller in 1958 during her study on Wealden Basin (Hunt, 1996). Vitrinite is a maceral that derived from partial decomposition and thermal alteration of lignin and cellulose tissues of higher plants that found in several types of kerogen. Although, three main groups of macerals are existing but the reflectance measurement only carried out on the vitrinite group because the other macerals like liptinite and inertinite are mature at different degrees (Peters et al., 2005). According to Petersen et al. (2013), the reflectance of vitrinite maceral increases with increasing temperature due to condensation and successive ordering of aromatic structure in the degraded ligno-cellulose materials to form vitrinite. It is too hard to recognize the macerals when maturity increase because their structural features become less distinct, the fluorescence decrease and reflectance increase (Killops and Killops, 2005).

Three cutting samples at depths of $3245 \mathrm{~m}, 3280 \mathrm{~m}$ and $3330 \mathrm{~m}$, in addition to one core sample at depth of $3307 \mathrm{~m}$ have been selected from Sargelu Formation in Tq-1 well, based on their richness with the total organic carbon content (TOC wt.\%), in order, to determine the level of thermal maturity of the existed organic matter within Sargelu Formation. Maceral identification and reflectance measurements were conducted at the Department of Geology, University of Patras, Greece. The polished blocks were examined by using a Leica DMRX coal-petrography microscope (under white incident light, and blue light excitation for fluorescence mode); using an oil-immersion 50x objective; with a total magnification of 500x. The classification of solid hydrocarbons is based on Landis and Castaño (1995) terminology. Reflectance measurements followed the procedure established for dispersed organic matter and described in ASTM D7708 (2014). Petrographic analysis of organic matters in three selected cutting samples (at depths of $3245 \mathrm{~m}, 3280 \mathrm{~m}$ and $3330 \mathrm{~m}$ ), and one core sample at depth of $3307 \mathrm{~m}$ of the Sargelu Formation in well Tq-1, revealed some interesting results. The most common organic particle in the selected samples is solid bitumen, which is a solid hydrocarbon under different terms such as migrabitumen, pyrobitumen, asphalt and dead oil. Moreover, it is defined as the accumulation of 
hydrocarbons in a solid phase that generated from a source rock or may possibly be migrated from another source to the host rock (Landis and Castaño, 1995; Petersen et al., 2013). Solid bitumen are amorphous organic matters, their shapes modified from the cavities and holes they inhabit (Riediger, 1993). The Migrabitumen development starts at the top of oil window with a vitrinite reflectance around 0.35 to $0.6 \%$ (Jacob, 1989).

The Sargelu Formation was deposited in a marine carbonate dominated environment (e.g. Bellen et al., 1959). Such an environment is usually characterized by absence or smaller amount of land derived organic matters (i.e. vitrinite particles). Thus, the examined samples of the Sargelu Formation in in this study were characterized by limited number of vitrinite particles as only 3 particles were counted. As a result, the solid bitumen reflectance $\left(\mathrm{BR}_{\mathrm{o}}\right)$ was used to represent vitrinite reflectance through applying the equation proposed by Jacob (1989) (Eq.1) (Table 6).

$$
\mathrm{VR}_{\mathrm{o}}=0.618 *\left(\mathrm{BR}_{\mathrm{o}}\right)+0.40
$$

Table 6. Values of vitrinite equivalent reflectance for four samples of the Sargelu Formation in well Tq-1 using Jacob's (1989) equation for converting the bitumen reflectance to vitrinite reflectance.

\begin{tabular}{ccc}
\hline Sample & Depth (m) & VRo\%, Jacob (1989) \\
\cline { 1 - 3 } A & 3245 & 1.15 \\
B & 3280 & 0.85 \\
C & 3307 & 1.04 \\
D & 3330 & 0.96 \\
\hline
\end{tabular}

The calculated VRo\% values for the examined samples of the Sargelu Formation (Table 7) indicate to thermally mature organic matters at the peak of oil generation maturity. The calculated VRo\% values showed relatively lower thermally mature level than the obtained maturity levels through the pyrolysis method. The encountered organic matters in the selected samples of the Sargelu Formation in well Tq1 encompass different types of components although dominated by solid bitumen. Their micrographs in Figs. $21-24$ show the observed organic particles which are further detailed below:

- Homogenous Bitumen: homogenous fragments of bitumen are common particles similar to microgranular bitumen. However, their homogenous characteristic simplifies the measurement of their reflectance than those of microgranular bitumen, because of the conceivable combination of bitumen with minerals in the microgranular bitumen (Landis and Castano, 1995). The homogeneous bitumen is well presented in Figs. 21A and B and Fig. 24A for the studied samples of the Sargelu Formation in well Tq-1 at depths 3245 and $3330 \mathrm{~m}$.

- Microgranular Bitumen: according to Tylor et al. (1998), these solid bitumen grains are often existing in sapropelic source rocks. The selected analyzed samples of the Sargelu Formation characterized by the frequent existence of this bitumen type as shown in Figs. 23A and B and Fig. 24D. This may be used for the maturity assessment because of their high quantity and close association with the mineral matrix (autochthonous secondary organic matter).

- Inertinite: This type of grain is mostly made up of indeterminate fragments of inertodetrinites and semifusinite. No reflectance measurements could be done on inertinite. However, in the studied samples, inertinite only exists in one sample at $3245 \mathrm{~m}$ depth as shown in Fig. 21C.

Vitrinite-like Particles: They comprise of regular fragments that exist in two selected samples $\mathrm{C}$ and D at 3307 and $3330 \mathrm{~m}$ depth respectively as shown in Fig. 21A and B and Fig. 24B. In addition, the existence of pyrite mineral is identified at the same mentioned depths of the previous selected samples of the Sargelu Formation in well Tq-1. This may indicate to the prevailing of anoxic sulfatic depositional environment (Hunt, 1996). 


\section{Discussion}

\subsection{Hydrocarbon Potential of the Sargelu Formation Source Rocks}

A general comparison between various organic geochemical properties of the Sargelu source rocks from different locations by various authors is illustrated in Table 7. Such a comparison included the organic matter richness (average TOC wt\%), quality of the existed organic matters (Kerogen type), the thermal maturity of the formation, and the ability of the formation for generating hydrocarbons (Genetic Potential, S1+S2). The Sargelu Formation in the studied locations has good to excellent TOCwt $\%$ contents except in the Qara Chauq Field where the formation is of fair organic matter content $(<1.0 \mathrm{TOCwt} \%)$ (Al-Ahmed, 2006). In addition, exceptionally high TOC values reported in the Makhule and Tawke fields where 13.04 and 16.22 average TOCwt $\%$ were recorded respectively. In most studied areas, the Sergelu Formation is dominated by type II and III kerogen types showing them as oil and gas prone source rocks. However, type IV kerogen is also commonly reported in other different locations within Iraq. The existence of the highly oil prone type I kerogen is only noticed in the Sargelu Formation in the Duhok region of northern Iraq (Hussein et al., 2013).
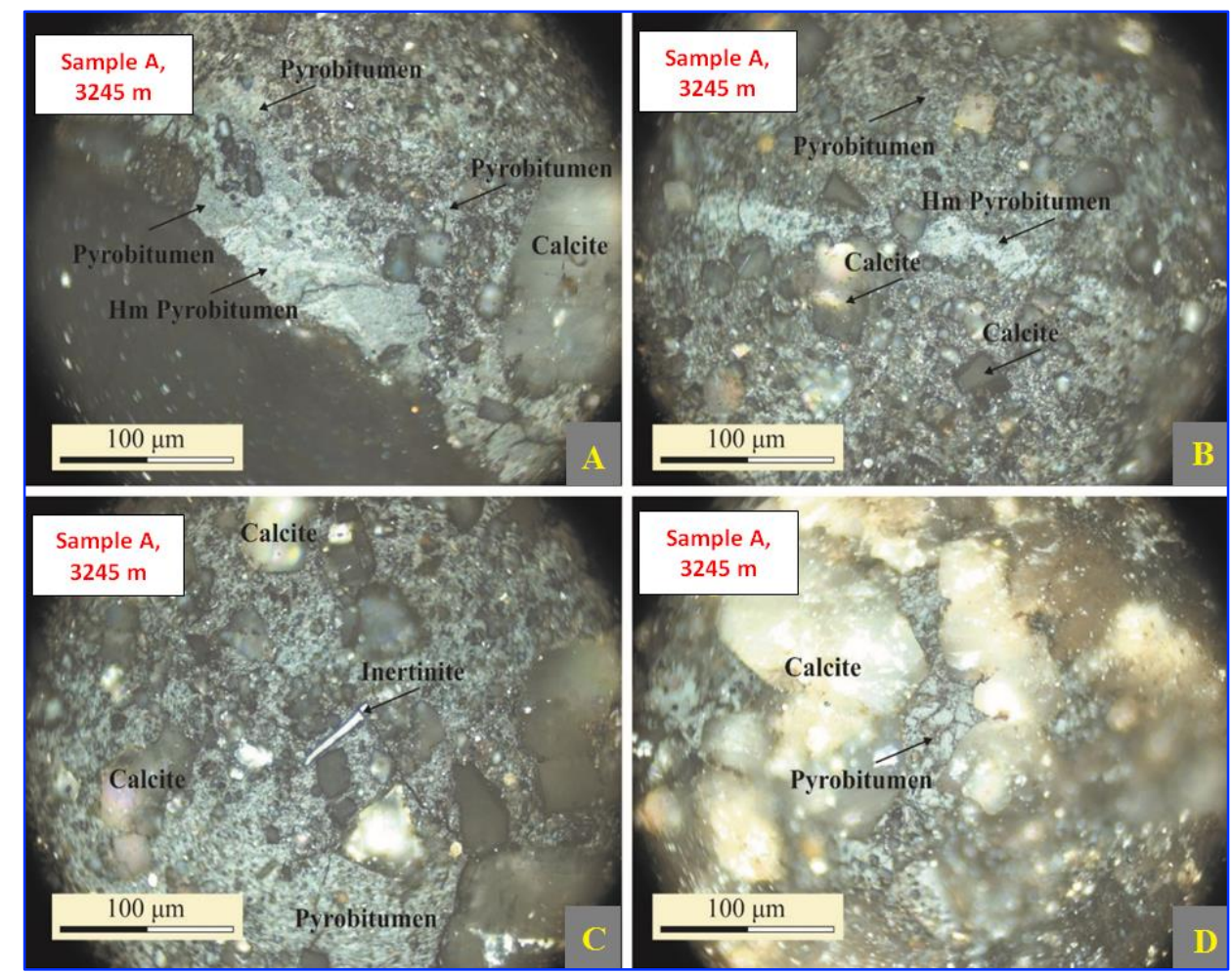

Fig.21. Photomicrographs of the sample A of the Sargelu Formation at depth of $3245 \mathrm{~m}$ in well Tq-1.

Microgranular pyrobitumens and homogenous bitumens as a network texture and infilling the intercrytslline spaces. However, this sample is also rich in carbonates as calcite cement and grains. Inertinite grains can be seen in photomicrograph $\mathrm{C}$.

Regarding thermal maturity state, the Sargelu Formation showed a range of maturity between immature to post mature (gas generation). Highest maturity observed in the Taq Taq and Miran fields the Zagros Fold Belt (High Folded Zone), which shows similarity to the Abadan Plain and north Dezful Zone of the Iranian Zagros Basin (Kobraei et al., 2019). On the other hand, the formation reported immature to early mature in the uppermost part of Northern Iraq in the Twake Field and Duhok region. So, the Sargelu Formation looks to be currently within different stages of oil generation in other locations shown in Table 7. Depending on the obtained petroleum potentiality (PP, S1+S2) values from 
pyrolysis analysis technique (Table 7), the Sargelu Formation as a source rock has potentiality for generating hydrocarbons ranging between poor ( $<3.0 \mathrm{mg} \mathrm{HC} / \mathrm{g}$ rock) and excellent ( $>24 \mathrm{mg} \mathrm{HC} / \mathrm{g}$ rock) and that according to the standard proposed by Peters and Cassa (1994).

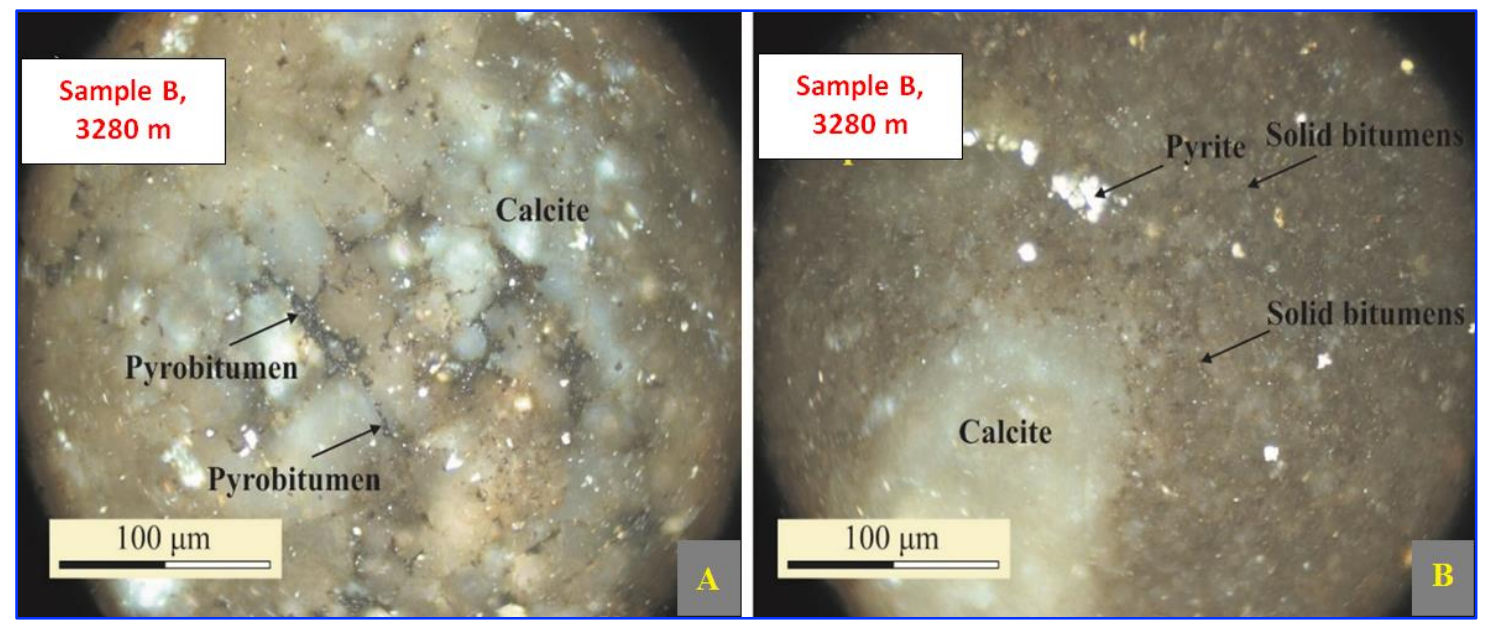

Fig.22. Photomicrograph showing the microgranular pyrobitumens of a network texture, infilling intercrytslline spaces of sample B at $3280 \mathrm{~m}$ depth in well Tq-1. This sample is rich in calcite. The clay-rich grains are also rich in framboidal and massive pyrite very fine amorphous, weakly fluorescent organic matter together with fine microgranular migrabitumens.

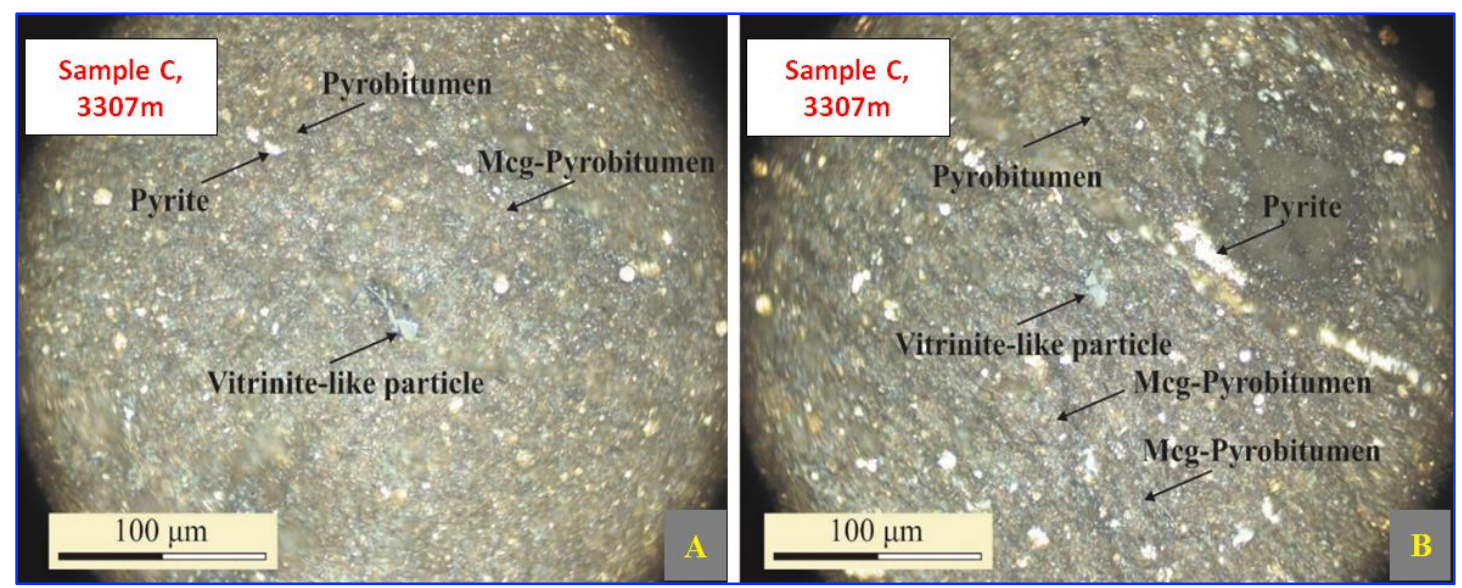

Fig.23. Photomicrograph of the sample $\mathrm{C}$ at $3307 \mathrm{~m}$ depth in well Tq-1 display the groundmass of clays admixtured with fine-grained amorphous non-fluorescing organic matter (i.e. microgranular migrabitumens) and microgranular pyrobitumens. The latter are frequently associated with the carbonates-rich fraction infilling the intercrytslline spaces. Framboidal and massive pyrite with vitrinite-like particles are also exist in this sample.

Although the PP value generally reflects the richness of the source rock by TOC and their kerogen type, and because those two parameters have no clear geographic distribution pattern for the Sargelu Formation, therefore no specific geographical distribution has been recognized for the generation potentiality of the formation. Generally, the Sargelu Formation in the northern parts of Iraqi Kurdistan Region (including Duhok, Tawke, and Atrush areas) and in the Makhule Field characterized by higher petroleum potentiality when compared with the other locations mentioned in Table 7. The most similar recorded source rock properties for the Sargelu Formation in the present study of Taq Taq Field are those been recorded in the Miran Field (Fatah and Mohialdeen, 2016) within Iraqi Kurdistan Region and in the Abadan Plain and north Dezful Zone of the Iranian Zagros Basin (Kobraei et al., 2019). 

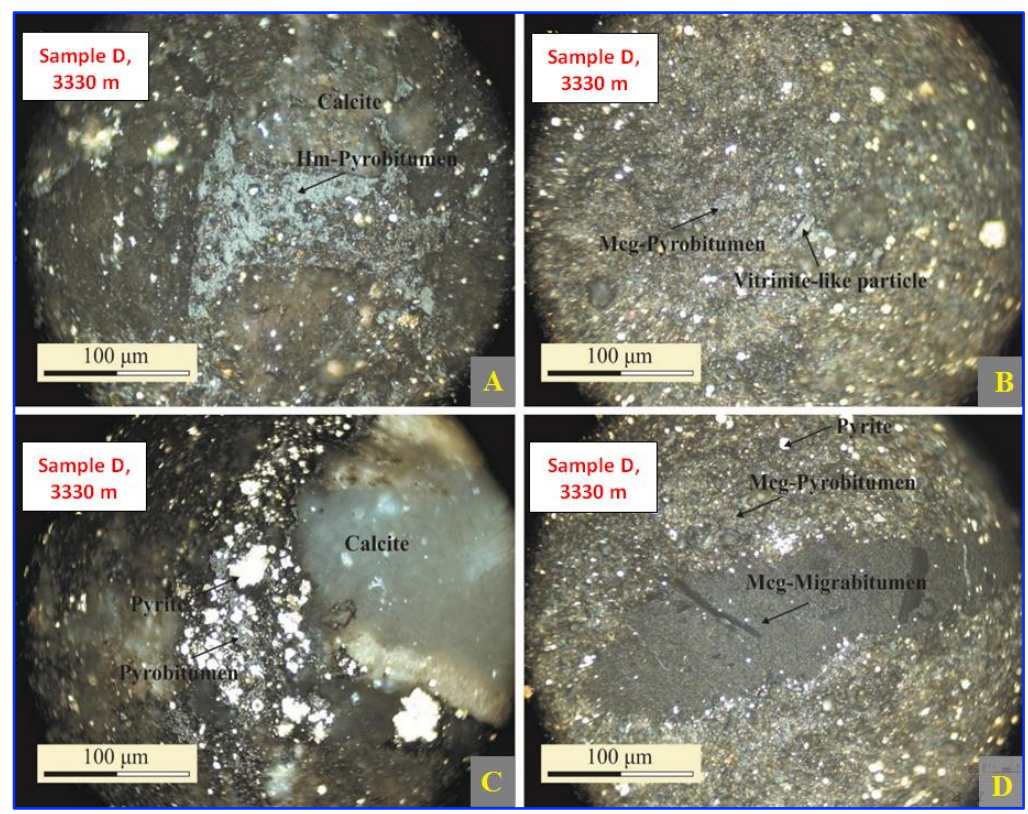

Fig.24. Photomicrograph of the sample D at $3330 \mathrm{~m}$ depth in well Tq-1, show the clay rich groundmass admixtured with fine-grained amorphous non-fluorescing organic matter (i.e. microgranular migrabitumens), microgranular, and homogenous pyrobitumens. The latter are more often associated with calcite rich fraction. Vitrinite-like particles, framboidal and massive pyrite are also existing

Table 7. The hydrocarbon potential results of the current study compared to other studies performed on the source rocks of the Sargelu Formation in various localities across Iraq

\begin{tabular}{|c|c|c|c|c|c|c|}
\hline Author and Year & Loc & & $\begin{array}{l}\text { TOC } \\
\text { wt\% }\end{array}$ & Kerogen Type & $\begin{array}{l}\text { Thermal } \\
\text { Maturity }\end{array}$ & $\begin{array}{c}\text { Hydrocarbon } \\
\text { Potentiality (Peters } \\
\text { and Cassa, 1994) }\end{array}$ \\
\hline This study & Zagros Fold Belt & Taq Taq Field & 3.03 & $\begin{array}{c}\text { III \& IV } \\
\text { (gas prone) }\end{array}$ & $\begin{array}{l}\text { late oil to wet } \\
\text { gas generation } \\
\text { window }\end{array}$ & Poor-Good \\
\hline $\begin{array}{l}\text { Al-Habba and } \\
\text { Abdullah, } 1989\end{array}$ & Zagros Fold Belt & $\begin{array}{l}\text { Qara Chauq } \\
\text { Field }\end{array}$ & 4.94 & $\begin{array}{l}\text { II (oil and gas } \\
\text { prone) }\end{array}$ & Early oil zone & Very good \\
\hline \multirow{6}{*}{$\begin{array}{l}\text { Al-Ahmed (2006); } \\
\text { Al-Ameri et al. } \\
\text { (2014); } \\
\text { Najaf (2018); } \\
\text { Hakimi et al. } \\
(2018)\end{array}$} & \multirow{6}{*}{ Northern Iraq } & Butmah Field & 1.22 & $\begin{array}{l}\text { III \& IV } \\
\text { (gas prone) }\end{array}$ & Oil zone & Poor-Fair \\
\hline & & $\begin{array}{l}\text { Qara Chauq } \\
\text { Field }\end{array}$ & 0.86 & $\begin{array}{l}\text { II, III, \& IV } \\
\text { (oil \& gas } \\
\text { prone) }\end{array}$ & Oil zone & Fair-Good \\
\hline & & Taq Taq Field & 1.62 & $\begin{array}{l}\text { III \& IV } \\
\text { (gas prone) }\end{array}$ & $\begin{array}{c}\text { Oil } \\
\text { zone - Gas zone }\end{array}$ & Poor-Fair \\
\hline & & Makhule Field & 13.04 & $\begin{array}{l}\text { II, III, \& IV } \\
\text { (oil \& gas } \\
\text { prone) }\end{array}$ & Oil zone & Excellent \\
\hline & & $\begin{array}{l}\text { Jabal Kand } \\
\text { Field }\end{array}$ & 1.88 & $\begin{array}{c}\text { II \& III } \\
\text { (gas prone) }\end{array}$ & Oil zone & Fair-Good \\
\hline & & Ajil Field & 2.34 & $\begin{array}{l}\text { III \& IV } \\
\text { (gas prone) }\end{array}$ & Oil zone & Poor-Excellent \\
\hline $\begin{array}{l}\text { Hussein et al } \\
(2013)\end{array}$ & Iraqi Kurdistan & Duhok Area & 4.69 & I \& II & $\begin{array}{l}\text { Immature - Early } \\
\text { mature }\end{array}$ & Excellent \\
\hline \multirow{3}{*}{ Abdula (2015) } & \multirow{3}{*}{$\begin{array}{l}\text { Iraqi Kurdistan } \\
\text { (Zagros Fold } \\
\text { Belt) }\end{array}$} & Guwear Field & 1.3 & $\begin{array}{l}\text { II \& III (oil \& } \\
\text { gas prone) }\end{array}$ & Oil zone & Poor - Good \\
\hline & & Tawke Field & 16.22 & $\begin{array}{l}\text { II \& III (oil \& } \\
\text { gas prone) }\end{array}$ & $\begin{array}{l}\text { Immature - Oil } \\
\text { zone }\end{array}$ & Poor- Excellent \\
\hline & & Hawler Field & 1.73 & $\begin{array}{l}\text { II (oil and gas } \\
\text { prone) }\end{array}$ & Early oil zone & Fair- Good \\
\hline $\begin{array}{l}\text { Fatah and } \\
\text { Mohialdeen } \\
(2016)\end{array}$ & Zagros Fold Belt & Miran Field & 2.48 & $\begin{array}{c}\text { III \& IV } \\
\text { (gas prone) }\end{array}$ & $\begin{array}{c}\text { Post mature (Gas } \\
\text { zone) }\end{array}$ & Poor-Fair \\
\hline $\begin{array}{l}\text { Kobraei et al. } \\
(2019)\end{array}$ & $\begin{array}{c}\text { Iranian Zagros } \\
\text { Basin }\end{array}$ & $\begin{array}{l}\text { Abadan Plain } \\
\text { and north } \\
\text { Dezful zone }\end{array}$ & 3.8 & $\begin{array}{l}\text { II, III, \& IV } \\
\text { (oil \& gas } \\
\text { prone) }\end{array}$ & $\begin{array}{l}\text { late oil to wet } \\
\text { gas generation } \\
\text { window }\end{array}$ & Poor-Good \\
\hline Mamasani (2020) & Zagros Fold Belt & Atrush Field & 4.35 & $\begin{array}{l}\text { II (oil and gas } \\
\text { prone) }\end{array}$ & Early oil zone & Excellent \\
\hline
\end{tabular}




\section{Conclusions}

Petrographically, three main types of microfacies were identified in the Sargelu Formation. They are namely; Foraminiferal packstone/grainstone microfacies (common in the lower and the upper parts of the formation), Fossiliferous packstone microfacies, and Foraminiferal Wackestone. These facies association may indicate that the Sargelu Formation in the study area was deposited in the middle to outer ramp carbonate environment. As a source rock, the Sargelu Formation at the studied well contains a very good quantity of organic matter with an average of 3.03\% TOC. The distinguished kerogen types in the formation are mostly of type III and IV with the ability to generate gas and oil. Pyrolysis results and the colour of the organic matter components indicate that the Sargelu Formation is currently at postmature state (i.e. gas generation stage), with limited remaining potential for generating hydrocarbons. Amorphous Organic Matters dominant the organic matters of the Sargelu Formation with $>70 \%$, followed by $10-25 \%$ of phytoclast and less than $10 \%$ of palynomorphs. These organic matter association may prove that the Sargelu Formation was deposited in a distal suboxicanoxic basinal environment.

The comparison between this study results and previous published results (Table 7), shows that the Sargelu Formation generally contains sufficient organic matters to be considered as a rich source rock. Regarding quality of the organic matters, the Sargelu Formation contains various types of kerogen including types II, III, and IV (i.e. oil and gas prone) reflecting nature of the precursors and ecology of the paleo-depositional environment. The Sargelu Formation can be found at different stages of thermal maturity ranging between early stage of oil formation and stage of wet gas - condensate generation (i.e. post-mature stage). Although Sargelu Formation in most of the studied areas is of good hydrocarbon potentiality, but still in some locations shows poor to fair hydrocarbon potentiality and that due to containing type III and IV kerogens exclusively (Table 7). The thermal maturity of the Sargelu Formation depending on the calculated VRo\% reveals that the formation in the study area is currently at the peak of oil generation. The Sargelu Formation can be classified as an Effective source rock, according to the definitions suggested by Law (1999) for different source rock types, as the formation appears to have already generated and expelled hydrocarbons.

\section{Acknowledgements}

The authors are very grateful to the Geology Department of the Northern Oil Company, Kirkuk, for providing the cutting rock samples used in this study. They also very grateful to Dr. Polla Khnaqa from Kurdistan Institute for Researches and Strategic Studies (KIRSS) and for Dr. Stavros Kalaitzidis from Department of Geology, University of Patras, Greece, for their assistance in preparing the polished blocks and the organic petrography examinations. The authors are grateful to the Editor in Chief Prof. Dr. Salih M. Awadh, the Secretary of Journal Mr. Samir R. Hijab and the Technical Editors for their great efforts and valuable comments.

\section{References}

Abdula, R., 2010. Petroleum Source Rock Analysis of the Jurassic Sargelu Formation, Northern Iraq, M.Sc. Thesis (unpublished), University of Colorado, United States.

Abdula, R.A., 2015. Hydrocarbon potential of Sargelu Formation and oil-source correlation, Iraqi Kurdistan. Arabian Journal of Geoscience. 8, 5845 - 5868.

Ahmed, A. A., 2001. Palynofacies Indications of Depositional Environment and Source Potential for Hydrocarbon -Middle Jurrasic (Sargelu Formation), Northern Iraq. MSc Thesis (unpublished), Baghdad University, Iraq. 
Al-Ahmed, A.A., 2006. Organic Geochemistry, Palynofacies and Hydrocarbon Potential of Sargelu Formation (Middle Jurassic) Northern Iraq. Ph.D. Thesis (unpublished). University of Baghdad, Iraq.

Al-Qayim, B., Qadir, F., Al-Biaty, F., 2010. Dolomitization and porosity evaluation of the Cretaceous Upper Qamchuqa (Mauddud) Formation, Khabbaz Oil Field, Kirkuk Area, Northern Iraq. GeoArabia. 15(4), 4976.

Akinlua, A, Ajayi, T.R., Jarvie, D.M. and Adeleke, B.B., 2005. A re-appraisal of the application of rock- eval pyrolysis to source rock studies in the Niger Delta, Journal of Petroleum Geology. 28, 39-48.

Al-Ameri, T.K., Najaf, A.A., Al-Khafaji, A.S., Zumberge, J. and Pitman, J., 2014. hydrocarbon potential of the Sargelu Formation, North Iraq, Arabian Journal of Geoscience. 7(3), 987-1000.

Alaug, A.S., Mahmoud, M. S., Deaf, A.S. and Al-Ameri, T.K., 2014. Palynofacies, organic geochemical analyses and hydrocarbon potential of some Upper Jurassic-Lower Cretaceous rocks, the Sabatayn-1 Well, Central Yemen, Arabian Journal of Geoscience. 7(6), 2515 - 2530.

Al-Habba, Y.K. and Abdullah, M.B., 1989. A geochemical study of hydrocarbon source rock in Northwestern Iraq. Oil and Arab Cooperation Journal. 15, 11-51.

Al-Qayim, B. and Othman, D., 2012. Reservoir characterization of an intra-orogenic carbonate platform: Pila Spi Formation, Taq Taq Oil Field, Kurdistan, Iraq. Geological Society of London, 370, 139-168.

Al-Qayim, B. and Rashid F., 2012. Reservoir characteristics of the Upper Qamchuqa Formation (Albian) at Taq Taq Oil Field, Kurdistan Iraq. Journal of Petroleum Geology. 35(4), 214 - 259.

Aqrawi A.A.M., Goff, J.C., Horbury, A.D. and Sadooni, F.N., 2010. Petroleum Geology of Iraq, Scientific press Lt Po box 21, Beaconsfield, Bucks HP9 1NS, UK.

Aqrawi, A.A.M. and Badics, B., 2015. Geochemical characterization, volumetric assessment and shale-oil/gas potential of the Middle Jurassic -Lower Cretaceous Source Rocks of NE Arabian Plate. GeoArabia. 20(3), 99-140.

ASTM D7708, 2014. Standard Test Method for Microscopical Determination of the Reflectance of Vitrinite Dispersed in Sedimentary Rocks. Standard by ASTM International, USA.

Awdal, A.H., Braathen, A., Wennberg, O.P., and Sherwani, G.H., 2013. The characteristics of fracture networks in the Shiranish Formation of the Bina Bawi Anticline; Comparison with the Taq Taq Field, Zagros, Kurdistan, NE Iraq, Petroleum Geosciences. 19, 139-155.

Bacon, C.N., Calver, C.R., Boreham, C.J., Lenman, D.E., Morrison, K.C., Revill, A.T. and Volkman, J.K., 2000. The petroleum potential of onshore tasmania: A review, Geological Survey Bulletin. 71, 1-93.

Baban, D.H. and Sarraj, R.H., 2007. Palynofacies analysis and hydrocarbon generation potential of Dokan and Gulneri Formations (Upper Cretaceous) from Selected Wells in Northern Iraqi Oil Fields. Kirkuk University Journal Scientific Studies. 2(3), 17-34.

Baban, D.H. and Ahmed, S.M., 2009. Biomarker indicators of source and depositional environment for the organic matters within Barsarin Formation (Upper Jurassic) in Kirkuk and Taq Taq Oil Fields, Northern Iraq. Kirkuk University Journal-Scientific Studies. 3(1), 51-72.

Baban, D.H., and Ranyayi, K.S., 2013. Potentiality of Paleocene source rocks and their contribution in generating the accumulated oil in the Eocene Pila Spi Reservoir in Taq Taq Oil Field, Kurdistan Region, Iraq, Arabian Journal of Geosciences. 6(11), 4225- 4237.

Baban, D.H., Qadir, F.M. and Mohammed, A.R., 2020. Reservoir rock properties of the Upper Cretaceous Shiranish Formation in Taq Taq Oilfield, Iraqi Kurdistan Region. Journal of Zankoy Slemani, 22 (1), 363 388.

Batten, D.J., 1996. Palynofacies and Paleoenvironmental Interpretation (Chapter 26), In; Jansonius, J. and Gregore, D.C. (Eds.), Palynology/; Principles and Applications. American Associations of Stratigraphic Palynologists Foundation. 3, 1011-1064.

Balaky, S.M.H., 2004. Stratigraphy and Sedimentology of Sargelu Formation (Middle Jurassic) in Selected Sections in Erbil and Duhok Governorates-Iraqi Kurdistan, M.Sc. Thesis (unpublished), University of Salahaddin, Kurdistan Region, Iraq.

Bellen, R.C. van, Dunnington, H.V., Wetzel, R. and Morton, D.M., 1959. Lexique Stratigraphique International, Asie, Fascicule10a, Iraq, Paris. 333p.

Buday, T., 1980. The Regional Geology of Iraq, Volume 1, Stratigraphy and Paleogeography, Dar Al-Kutub publishing house, University of Mosul, Iraq. 445p. 
Dunham, R.J., 1962. Classification of Carbonate Rocks According to Depositional Texture. In: Ham, W.E., (Ed.), Classification of Carbonate Rocks. American Association of Petroleum Geologists, Mem.1, 108-121.

English, J.M., Fowler, M., Johnston, S.T., Mihalynuk, M.G., and Wight, K.L., 2004. The Thermal Maturity in the Central Whitehorse Trough, Northwest British Columbia, Resource Development and Geosciences Branch, British Columbia Ministry of Energy and Mines. 79 - 85.

English, J.M., Lunn, G.A., Ferreira, L. and Yacu, G., 2015. Geologic evolution of the Iraqi Zagros, and its influence on the distribution of hydrocarbons in the Kurdistan Region. American Association of Petroleum Geologists Bulletin. 99(2), 231- 272.

Espitalié, J., Laporte, J.L., Madec, M., Marquis, F., Leplat, P., Paulet, J. and Boutefeu, A., 1977. Rapid Method for Source Rocks Characterization and for Determination of Petroleum Potential and Degree of Evolution: Revue De L'institut Français Du Pétrole (IFP). 32(1), 23 - 42.

Fatah, S.S. and Mohialdeen, I.M.J., 2016. Hydrocarbon generation potential and thermal maturity of Middle Jurassic Sargelu Formation in Miran Field, Sulaimani Area, Kurdistan Region, NE Iraq. Journal of Zankoy Slemani A., GeoKurdistan, II, 213-228.

Flugel, E., 2010. Microfacies of Carbonate Rocks (Analysis, Interpretation and Application, 2nd Edition), Springer, Heidelberg, Germany.

Garland, C.R., Abalioglu, I., Akca, L., Cassidy, A., Chiffoleau, Y., Godail, L., Grace, M.A.S., Kader, H.J., Khalek, F., Legarre, H., Nazhat, H.B. and Sallier, B. 2010. Appraisal and Development of the Taq Taq Field, Kurdistan Region, Iraq. In: Vining, B.A. and Pickering, S.C. (Eds.) Petroleum Geology: From Mature Basins to New Frontiers - Proceedings of the $7^{\text {th }}$ Petroleum Geology Conference. Geological Society, London. 7, 801-810.

Gehman H.M.J., 1962. Organic matter in limestones. Geochimica et Cosmochimica Acta. 26(8), 885-97.

Hakimi, M.H., Najaf, A.A., Abdula, R.A. and Mohialdeen, I.M.J., 2018. Generation and expulsion history of oilsource rock (Middle Jurassic Sargelu Formation) in the Kurdistan of North Iraq, Zagros Folded Belt: Implications from 1D Basin Modeling Study. Journal of Petroleum Sciences and Engineering, 162, 852872.

Hunt, J.M., 1996. Petroleum Geochemistry and Geology (Second Edition), Freeman and Company, New York, USA. 743p.

Hussein, F.S, El Kammar, M.M, and Sherwani, G.H., 2013. Organic geochemical assessment of Jurassic Source Rock from Duhok, North Iraq. Journal of American Science. 9(1), 258-264.

IOEC, 1994. The Annual Report of the Discovered and Evaluated Oilfields for the year 1993, (unpublished), Iraqi Oil Exploration Company, Baghdad, Iraq.

Jacob, H., 1989. Classification, structure, genesis, and practical importance of natural solid bitumen, International Journal of Coal Geology. 11(1), $65-79$.

Jassim, S.Z. and Buday, T., 2006. Late Toarcian-Early Tithonian (Middle-Late Jurassic Megasequence AP7 (Chapter 10), In: Geology of Iraq, (1st ed.), Jassim, S.Z., and Goff, J.C. (Eds.), Brno, Czech Republic: Dolin, Prague and Moravian Museum. 117 - 123.

Jassim, S.Z. and Goff, J.C. 2006. Geology of Iraq. Dolin, Prague and Moravian Museum, Czech Republic. 341pp.

Johannes, J., Kruusement, K., Palu, V., Veski, R., and Bojesen, J.A., 2006. Evaluation of oil potential of Estonian shales and biomass samples using rock-eval analyzer, oil shale. 23(2), 110-118.

Katz, B.J., 2001. Geochemical investigation of sites 1108 and 1109, Leg 180, in; Huchon, P., Taylor, B., and Klaus, A. (Eeds.), Proceeding of the Ocean Drilling Program, Scientific Results. 180, 1-19.

Killops K. and Killops V., 2005. Introduction to Organic Geochemistry, Second Edition, Black Well Publishing, $393 \mathrm{p}$.

Kobraei, M., Sadouni, J. and Rabbani, A. R., 2019. Organic geochemical characteristics of Jurassic petroleum system in Abadan Plain and North Dezful Zones of the Zagros basin, Southwest Iran. Journal of Earth System Sciences. 128, 50p.

Landis, C.R. and J.R. Castaño, 1995. Maturation and bulk chemical properties of a suite of solid hydrocarbons, Organic Geochemistry. 22(1), 137-149.

Law, C.A., 1999. Evaluating Source Rocks ; in Beaumont E.A. and Foster N.H (Eds.), Treatise Petroleum Geology Handbook. American Association of Petroleum Geologists. 6.1 - 6.41. 
Mamaseni, W.J., 2020. Petroleum potentiality and petrophysical evaluation of the Middle-Jurassic Sargelu Formation, Northern Iraq. Iraqi Geological Journal. 53(2D), 77-93.

Murris, R.J., 1980. Middle East stratigraphic evolution and oil habitat, American Association of Petroleum Geologists. 64, $597-618$.

NOC, 1978. Final Report of Tq-1 well, Northern Oil Company, Kirkuk, Iraq.

Najaf, A.A., 2018. Basin modeling of the potential sourced Sargelu Formation within Zagros Fold Belt, North Iraq. Iraqi Bulletin of Geology and Mining, 14(1), 31-46.

Odisho, K.Y. and Othman, R.S., 1992. Preliminary geochemical evaluation of hydrocarbon source rock in Northern Parts of Iraq, Iraqi Geological Journal. 25(2), 136 - 153.

Othman, D. and Al-Qayim, B., 2010. Lithofacies association, dolomitization, and potentiality of the Pila Spi Formation, Taq Taq Oil Field, Kurdistan Region, NE Iraq. Iraqi Bulletin of Geology and Mining. 6(2), 95 -114 .

Othman, R.S., 2003. Petroleum Geology of Gunnedah-Bowen-Surat Basins, Northern New Wales (Stratigraphy, Organic Petrology and Organic Geochemistry), Ph.D. Thesis (unpublished), University of New South Wales, UK. 312 pp.

Pearson, D.L., 1990. Pollen, Spore Color 'standard: Bartlesville (Phillips Petroleum Co., Geology Branch).

Peters, K.E. and Cassa, M.R., 1994. Applied source rock geochemistry; In: Magoon, L. B. and Dow, W. G. (Eds.), The Petroleum System- from Source to Trap. American Association of Petroleum Geologists. Memoir 60, 93-120.

Peters, K.E., Walters, C.C. and Moldowan, J.M., 2005. The Biomarker Guide, Second Edition, Volume I, Biomarkers and Isotopes in Petroleum Systems and Human History, Cambridge University Press, UK. $471 \mathrm{p}$.

Petersen, H.I., Holme, A.C., Andersen, C., Whitaker, M.F., Nytoft, H.P. and Thomsen, E., 2013.The source rock potential of the Upper Jurassic-Lowermost Cretaceous in the Danish and Southern Norwegian Sectors of the Central Graben, North Sea. First Break، 31, 43 - 53.

Pitman, J.K., Steinshouer, D. and Lewan, M. D., 2004. Petroleum generation and migration in the Mesopotamian Basin and Zagros Fold Belt of Iraq, results from a basin modeling study: GeoArabia, Gulf Petro Link, Bahrain. 9(4), 41-72.

Riediger, C.L., 1993. Solid bitumen reflectance and rock-eval tmax as maturation indices: an example from the "Nordegg member", Western Canada Sedimentary Basin: International Journal of Coal Geology. 22, $295-315$.

Shaaban, F., Lutz, R., Littke, R., Bueker, C. and Odisho, K., 2006. Source-rock evaluation and basin modelling in NE Egypt (NE Nile Delta and Northern Sina)", Journal of Petroleum Geology. 29(2), 103 - 124.

Smith, J.T., 1994. Petroleum System Logic as an Exploration Tool in a Frontier Setting, Chapter 2. In: Magoon, L.B., and Dow, W.G. (Eds.), The Petroleum System from Source to Trap: American Association of Petroleum Geologists. Memoir 60, 25 - 49.

Thompson, C.L. and Dembicki, H.Jr. 1986. Optical characteristics of amorphous kerogens and the hydrocarbongenerating potential of source rocks. International Journal of Coal Geology. 6, 229 - 249.

Tissot, B.P. and Welte, D.H., 1978. Petroleum Formation and Occurrence: A New Approach to Oil and Gas Exploration. Springer-Verlag, Berlin. 538 pp.

Tissot, B.P. and Welte, D.H., 1984. Petroleum Formation and Occurrence: A New Approach to Oil and Gas Exploration (2nd Ed.): Springer - Verlag, Berlin. 699p.

Tissot, B.P., Pelet, R. and Ungerer, P.H., 1987. Thermal history of sedimentary basins, maturation indices and kinetics of oil and gas generation. American Association of Petroleum Geologists Bulletin. 71, 1445-1466.

Taylor, G.H., TeichmÜller, M., Davis, A., Diessel, C.F.K., Littke, R. and Rober, P., 1998. Organic Petrology, Handbook, Berlin; Stuttgart: Gebrudre Borntraeger. 704 pp.

Tyson, R.V., 1995. Sedimentary Organic Matter, Organic Facies and Palynofacies, Chapman and Hall, 615 pp.

Wetzel, R., 1948. Sargelu Formation, In: Bellen, R.C., Dunnington, H.V., Wetzel, R. and Morton, D.M. (Eds.), Lexique Stratigraphic International: Paris, v. III, Asie, Fascicule 10a Iraq. 250-253.

Whelan, J.K. and Thompson-Rizer, K.L., 1993. Chemical Methods for Assessing Kerogen and Protokerogen Types and Maturity, Organic Geochemistry, In: Engel, M.H., and Macko, S.A. (Eds.), Plenum Press, New York. $289-353$. 